

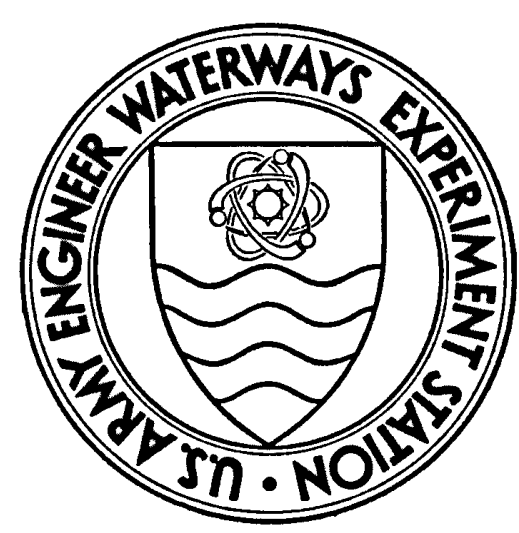

MISCELLANEOUS PAPER S-73-62

\section{PRESHOT MATERIAL PROPERTY INVESTIGATION FOR THE MIXED COMPANY SITE: SUMMARY OF SUBSURFACE EXPLORATION AND LABORATORY TEST RESULTS}

by

J. Q. Ehrgott

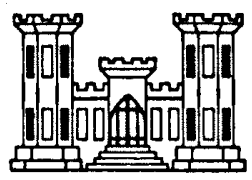

October 1973

Sponsored by Defense Nuclear Agency

Subtask SB209, Work Unit II, "Laboratory Studies of the Response of Soil and Rock to Blast-Type Loadings"

Conducted by U. S. Army Engineer Waterways Experiment Station Soils and Pavements Laboratory Vicksburg, Mississippi 
THE CONTENTS OF THIS REPORT ARE NOT TO BE USED FOR ADVERTISING, PUBLICATION, OR PROMOTIONAL PURPOSES. CITATION OF TRADE NAMES DOES NOT CONSTITUTE AN OFFICIAL ENDORSEMENT OR APPROVAL OF THE USE OF SUCH COMMERCIAL PRODUCTS. 
This report summarizes the investigations conducted under Project IN 310, "Soil Sampling and Laboratory Testing for Constitutive Relations," in support of Mixed Company Event III, a 500-ton, high-explosive experiment conducted near Grand Junction, Colorado. The primary purpose of Project IN 310 was to provide a representative geologic profile of the Mixed Company site along with associated constitutive properties for use in the preshot two-dimensional ground shock calculations planned under Project IN 312. This report describes results from (I) a field investigation program consisting of a geologic survey, a refraction seismic survey, and an exploration boring and sampling program; (2) a laboratory test program consisting of static and dynamic uniaxial strain tests, isotropic compression tests, triaxial shear tests, and static tension tests; and (3) the analyses applied to the data obtained from both of these programs in order to develop a recommended site profile and matching set of constitutive properties in time to support preshot calculations. Typical test data are presented to illustrate general trends and or response characteristics. 
This report is essentially a paper prepared for presentation at the Mixed Company/Middle Gust Project Review Meeting held at the DOD Nuclear Information and Analysis Center (DASIAC), Santa Barbara, California, 13-15 March 1973. It summarizes results of investigations conducted by the Soils and Pavements Laboratory (S\&PL) of the U. S. Army Engineer Waterways Experiment Station (WES) during the period August 1971 through July 1972 under Mixed Company Project IN 310, "Soil Sampling and Laboratory Testing for Constitutive Relations." The project was sponsored by the Defense Nuclear Agency (DNA) under NWE Subtask SB209, "Propagation of Ground Shock Through Earth Media." Mr. C. B. McFarland was the DNA Project Officer for Subtask SB209. Supporting studies were conducted by Terra Tek, Inc., (TT) and Stanford Research Institute (SRI) under separate DNA funding.

The LN 310 Project Officer was Mr. J. Q. Ehrgott of the Soil Dynamics Division, S\&PL, WES, who prepared and presented this paper. Drs. J. S. Zelasko and P. F. Hadala, Messrs. J. T. Gatz and R. E. Leach, and PVT J. R. Benham of the S\&PL, WES; Messrs. R. L. Stowe, B. R. Sullivan, and R. A. Bendinelli of the Concrete Laboratory, WES; Mr. S. J. Green of TT; and Dr. C. F. Peterson of SRI made substantial constibutions to the project. The work was conducted under the general direction of Dr. J. G. Jackson, Jr., Chief of the Soil Dynamics Division, S\&PL. Mr. J. P. Sale was Chief of S\&PL during the conduct of the study. BG E. D. Peixotto, CE, and COL G. H. Hilt, CE, were Directors of the WES during the investigation and the publication of this report. Mr. F. R. Brown was Technical Director. 
ABSTRACT-

PREFACE-

CONVERSION FACTORS, BRITISH TO METRIC UNITS OF MEASUREMENT-.....-

CHAPTER I INTRODUCTION-C.-

CHAPTER 2 FIELD INVESTIGATION-

2.1 Site Geology-

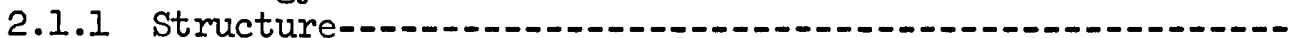

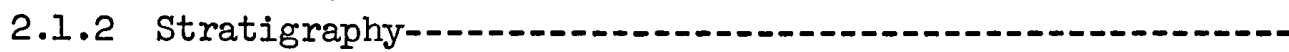

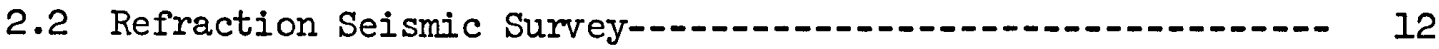

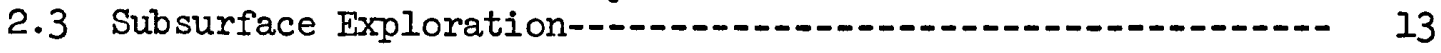

CHAPTER 3 LABORATORY TEST RESULTS-_-_- 27

3.1 Tests---1 27

3.2 Overburden Soil-_._. 28

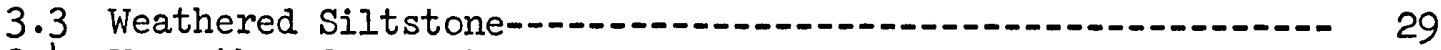

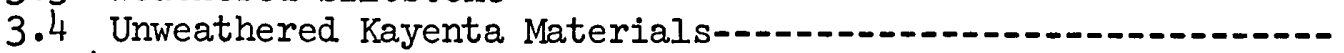

3.4.1 UX Gun Tests........

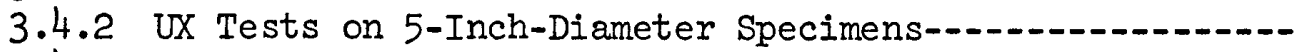

3.4.3 UX $\mathrm{K}_{\mathrm{O}}$ Tests-.-...-

3.4 .4 IC and TX Tests-.....

3.4.5, Tension Tests

CHAPTER 4 ANALYSIS-- 46

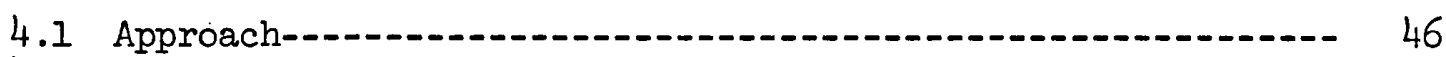

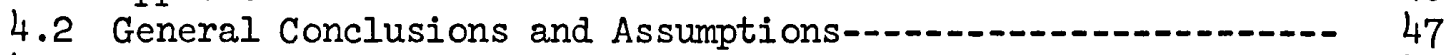

4.3 Specific Recommendations--.- 47

CHAPTER 5 EPILOG-_ 54

TABLES

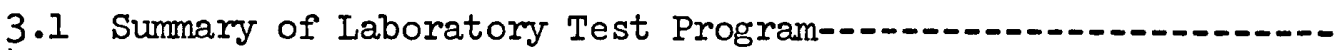

4.1 Conclusions and Assumptions Used to Develop Representa-

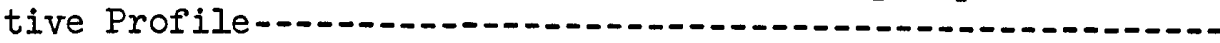

4.2 Conclusions and Assumptions Used to Develop Representa-

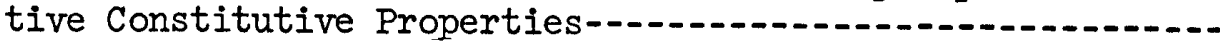

4.3 Representative Profile and Compositional Properties........-

2.I Stratigraphy column for Mixed Company site-.-.-.-.-.-.-.-.

2.2 Schematic fence diagram along boring lines showing subsurface profile as defined by field refraction seismic

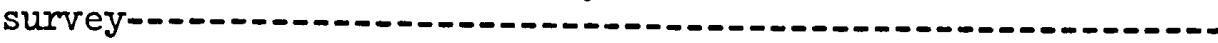

2.3 Plan view of the Mixed Company Event III site showing bor-

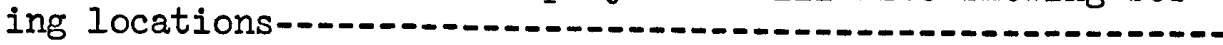

2.4 Composition properties of overburden soil zone- 
2.5 Composition properties of Kayenta Formation rocks-.....-.---

2.6 Schematic fence diagram showing the soil-rock interface as defined by borings compared with the interface defined by

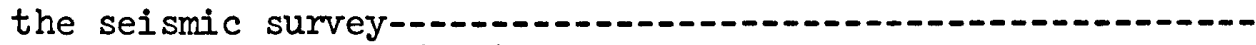

2.7 Rock quality index ( $R Q D$ ) of several borings compared with

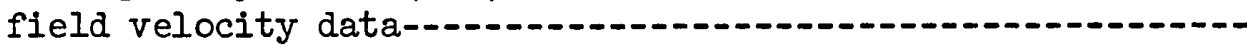

2.8 Idealized subsurface profile along main gage line indicating

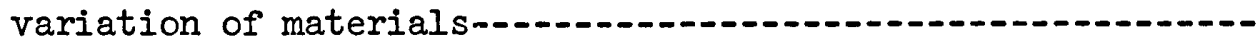

2.9 Water content of soil taken in July 1972 compared with water contents the day before and the day after Event III.........-

2.10 Original composition properties of Kayenta Formation and composition properties taken the day after Event III--.-.-.--

3.1 Results of UX tests on soil specimens remolded to different

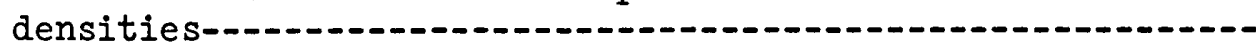

3.2 Results of UX gun tests showing response of air-dried sand-

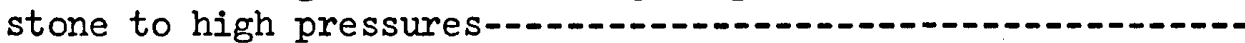

3.3 Typical dynamic UX test results for shallow (<25 feet)

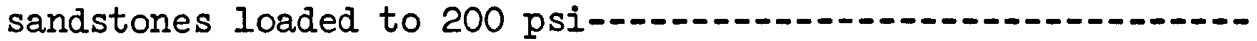

3.4 Typical dynamic UX test results on Kayenta materials from shallow (<25 feet) depths loaded to 2,000 psi-..............

3.5 Selected dynamic and static UX test results on Kayenta materials from shallow (<25 feet) depths loaded to 8,000 psi-3.6 Static $K_{0}$ test results on sandstones compared with representative UX stress path response-............................

3.7 Typical static and dynamic IC test results on shallow sandstone (<25 feet) -

3.8 Typical dynamic TX shear test results at various confining pressures showing the response of the clayey conglomerate material (from 20-foot depth) and the general response of

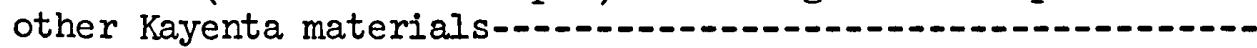

3.9 Mean normal stress versus volumetric strain showing the typical response of sandstones during TX shear-..........-. 44

3.10 Typical static and dynamic TX failure data for sandstones from shallow (<25 feet) depths -

4.1 Representative UX stress-strain loading and unloading relations for Layers I through V-...........................

4.2 Representative UX stress paths and TX failure envelopes for Layers I through V-...- 
British units of measurement used in this report can be converted to metric units as follows:

\begin{tabular}{lll}
\hline \multicolumn{1}{c}{ Multiply } & By & \multicolumn{1}{c}{ To Obtain } \\
\hline inches & 2.54 & centimeters \\
feet & 0.3048 & meters \\
miles (U. S. statute) & 1.609344 & kilometers \\
tons (2,000 pounds) & 907.185 & kilograms \\
pounds (force) per square inch & 0.6894757 & newtons per square centimeter \\
kips (force) per square inch & 0.6894757 & kilonewtons per square centi- \\
& \multicolumn{3}{c}{ meter } \\
pounds (mass) per cubic foot & 16.0185 & kilograms per cubic meter \\
feet per second & 0.3048 & meters per second
\end{tabular}




\section{INTRODUCTION}

Mixed Company Project IN 310, "Soil Sampling and Laboratory Testing for Constitutive Relations," was performed by the U. S. Army Engineer Waterways Experiment Station (WES) for the Defense Nuclear Agency (DNA) under NWE Subtask SB209. Terra Tek, Inc. (TT), and Stanford Research Institute (SRI) were also funded by DNA to support the project.

The Mixed Company program consisted of several high-explosive field tests, i.e., two 20-ton ${ }^{1}$ tests (Events I and II), and a 500-ton test (Event III). The primary objective of Project IN 310 was to provide a representative geologic profile for the Mixed Company Event III site location with associated constitutive properties in a form suitable for use in two-dimensional (2D) ground shock calculations. Constitutive property recommendations were disseminated in June 1972 and were used as a basis for the mathematical model formulations in the preshot ground- . shock calculations performed under Project LN 312, "Theoretical Ground Motion Calculations." In addition, a grout mixture whose properties approximately matched the constitutive properties of the underlying sandstone at this site was developed for use in the placement of instrumentation for the 500-ton event.

The purpose of this report is to summarize the results obtained from a field investigation program consisting of a geologic survey, a refraction seismic survey, and an exploratory boring and sampling program (Chapter 2); a laboratory test program consisting of static and dynamic uniaxial strain tests, isotropic compression tests, triaxial shear tests, and static tension tests (Chapter 3); and the analyses applied to the data obtained from both of those programs in order to develop a recommended site profile and matching set of constitutive properties (Chapter 4 ).

1

A table of factors for converting British units of measurement to metric units is presented on page 8 . 


\section{FIELD INVESTIGATI ON}

The geologic criterion for choosing the site of the Mixed Company tests was that the near-surface site profile should consist of a shallow stratum of sandy soil overlying a deep deposit of fairly homogeneous sandstone. During the summer of 1971, a preliminary geologic field survey and boring program was conducted at several possible site locations in Utah and in the Grand Junction, Colorado, area. Based on the information obtained from those studies, a site in Mesa County, Colorado, about 17 miles west-southwest of Grand Junction was selected. During the late summer and fall of 1971, the main field investigation was conducted at this site and consisted of an extensive surface refraction seismic survey, approximately 15 subsurface exploration borings, the opening of three test pits to expose the soil-rock interface, and mapping of the soil-rock interface across the site area through use of power auger borings. In February 1972, additional subsurface borings were drilled to obtain in situ water content and density measurements. Geologic inspections of the site were made during each investigation, in addition to laboratory classification tests and literature studies.

\subsection{SITE GEOLOGY}

The Mixed Company site, located in the northeasterm part of the canyon lands section of the Colorado Plateau physiographic province, is on a broad plain on the northern flank of the Uncompahgre Plateau. The plain dips 1 to 2 percent to the west and northwest in the area of the site. Severe to moderate erosion has exposed cliff faces in the immediate vicinity of the site. A mesa approximately 1 mile north of the site rises about 150 to 200 feet above the plain. A 100-foot-deep valley or canyon with vertical walls lies approximately 1/2-mile to the west. About 1 mile south of the site, the terrain falls abruptly 100 to 200 feet into another canyon (Trail Canyon). The formations that underlie the site are exposed in both canyons.

Small intermittent streams cross a portion of the site, but no 
continuous stream occurs within 2 miles of the site. The region drains into the Colorado River, which is located about 10 miles to the north and forms an arc around the northwestern end of the Uncompahgre Plateau. Most of the water used in the area is produced from deep wells that penetrate one or two water-bearing sandstone formations, i.e., the Entrada or the Wingate.

2.1.1 Structure. No evidence which would indicate the existence of major geologic faulting within the immediate site area was found. The closest mapped fault is the east-west trending Glade Park fault that appears to end about 4 miles east of the site. Several indications of minor faults appear in a mesa north of the Mixed Company site, but these are not believed to extend into the test area. South of the site, Mesozoic strata generally strike east-west. These strata dip less than 5 degrees to the north, i.e., away from the Uncompahgre Uplift. The existence of intermittent streams flowing north and west across the broad plain suggests that this, trend also exists at the test site.

2.1.2 Stratigraphy. A stratigraphy column of the site area is shown in Figure 2.1. The entire site is covered by a relatively thin (i.e., 1-to 8-foot-thick) deposit of sandy clayey silt. The soil appears to become slightly cemented with depth. Underlying the soil cover is the 70-foot-thick Kayenta Formation of the Glen Canyon Group and Triassic period. The uppermost portion consists of weathered siltstone (approximately 4 feet thick), resulting in a somewhat indistinguishable interface between it and the overlying soil cover. The Kayenta is a fluvial deposit (water lain) which consists of lenticular to irregularly bedded layers of fine- to medium-grained sandstone, siltstone, and conglomerate with occasional layers or-lenses of shale. Thus, there is a significant variation in the visual appearance of the samples from this formation although there were general correlations of materials between borings.

The Wingate Formation of the Glen Canyon Group lies beneath the Kayenta; it is encountered at a depth of approximately 70 feet and is believed to extend to about the 400-foot depth. It is a massive, finegrained, crossbedded sandstone whose origin is predominantly eolian 
(windblown). Because of its high porosity, it is one of the two waterbearing rocks found in the area.

Below the Wingate is the Chinle Formation, which is also of Triassic period. It was deposited on a widespread, low-lying alluvial plain with many lakes and consists mostly of red siltstone with thin, hard beds of limestone, conglomerate, and greenish siltstone. It is believed to extend to approximately the 500-foot depth where it rests unconformably on a very smooth erosional surface of the Precambrian basement rock. The Precambrian rock consists primarily of schist and gneiss with younger granitic intrusions.

The mesa north of the site consists of Jurassic rocks of the eolian Entrada Formation sandstone with a thin top cover of shale of the Sumersville-Morrison Formations. These formations have generally been eroded away from the test site area; however, it is possible that local surface pockets of Entrada sandstone may still exist at the site. The Entrada sandstone is similar to the Wingate sandstone and is also a water-bearing rock.

\subsection{REFRACTION SEISMIC SURVEY}

A surface refraction seismic survey was conducted at the site in September 1971. The survey followed the three main subsurface boring lines which were positioned 120 degrees apart and which radiated out from the then-proposed 500-ton ground zero (GZ) location. Most of the seismic investigations were conducted using a hammer source with 150foot lines and 15-foot geophone spacings. One 570-foot line was run using an explosive source to provide extended depth coverage.

The results indicated a low-velocity zone (2,000 to 3,000 fps) overlying a high-velocity zone $(6,000$ to $8,800 \mathrm{fps})$. A schematic fence diagram along the three boring lines is presented in Figure 2.2 to illustrate the subsurface profile as defined by the seismic survey. It should be noted that the final GZ location of Event III was at the location of Boring $\mathrm{ClO}$, as indicated in the diagram. The thickness of the low-velocity zone ranged from 9 to 15 feet. The results of the one deep survey indicated an additional higher velocity zone (14,000 fps) 
beginning at a depth of approximately 90 to 130 feet. The deep survey was conducted in line with Borings $\mathrm{C} 5$ to $\mathrm{C} 6$, but extended farther east (see Figure 2.2).

\subsection{SUBSURFACE EXPLORATION}

The subsurface exploration investigation was conducted to ( 1 ) identify the subsurface material within a 500-foot radius of GZ, (2) obtain sufficient samples of each type material encountered for the laboratory test program, (3) obtain measurements of in situ water content and density in the soil and rock materials, (4) inspect the soil-rock interface for jointing, and (5) map the depth to rock within the general area. The main field investigation conducted in the fall of 1971 accomplished those objectives with one exception, i.e., questionable data were obtained regarding the in situ water content of the rock material. The $\mathrm{NX}$-size core samples were allowed to air-dry after sampling and the 5-inch-diameter Shelby tube samples, drilled with water, were sealed. after sampling, thereby possibly trapping drilling water in the material. Therefore, an additional set of borings was drilled in February 1972 using both air and colored water as drilling coolants. Samples from these borings were sealed immediately after recovery. These samples also supplemented the supply for the laboratory test program.

A plan view of the site showing all boring locations, the final location of GZ for Event III, and the location of the WES main gage line is given in Figure 2.3. The holes designated " $\mathrm{C}$ " and " $\mathrm{U}$ " were drilled in September 1971; the holes designated "NXA" and "UA" were drilled in February 1972.

Power auger borings were made in a 50- by 50-foot grid pattern over the site in an attempt to determine the depth of the soil overburden. The depth of auger refusal, however, indicated a highly variable depth to the soil-rock interface; i.e., refusal ranged from 1 to 15 feet. In truth, there is no uniform soil-rock interface at the site due to the variable degree of weathering of the near-surface Kayenta siltstone. Results from the main subsurface borings and three test pits indicated 
a somewhat narrower variation in interface depth; i.e., a range from 1 to only 8 feet.

The variation of the composition properties of the soil zone with depth is shown in Figure 2.4. The average water content was between 5 and 6 percent. The wet density increased from 95 pcf at the surface to 120 pcf at the 3- to 4-foot depth.

The variation of composition properties with depth determined for the underlying rock is presented in Figure 2.5. The suspect water content data are not shown. Below the soil zone and above the 40-foot depth, a distinct horizontally layered profile is not evident in the composition property data. Since the questionable water content information was eliminated, the scatter in the composition properties is, most probably, due to the great variation in lithology (i.e., sandstones, siltstones, mudstones, and conglomerates) encountered in the Kayenta Formation.

Figure 2.6 is a schematic fence diagram along the boring lines showing the overburden soil thickness as defined from the borings. Superimposed on the same diagram is the layer interface as defined by the seismic survey. The cause of the apparent discrepancy is the variability of the weathered siltstone zone underlying the soil. Within this zone, the rock quality index $(R Q D)^{l}$ was nearly 0 percent down to the approximate depth of the interface defined by the seismic survey, i.e., an average depth of 9 feet. This indicates a broken rock transition zone approximately 3 to 4 feet thick; the density of this material increased from 130 to 140 pcf with depth.

The subsurface borings indicated that the sandstones and other rocks below the weathered zone had high RQD values ranging from 90 to 100 -percent. Figure 2.7 shows plots of RQD versus depth obtained from several borings as well as the average seismic velocity-depth profile. The RQD data indicate that below a depth of about 10 feet, the materials

1 RQD is defined as 100 times the ratio of total length of core pieces greater than 4 inches long to total length of drive. It is used as an engineering index to the quality of the in situ rock. 
are not badly fractured and that, if an open joint system consisting of nearly horizontal planes exists, the joints are not closely spaced. It should be noted that cores of the material could, however, easily be pulled apart along thin clay laminations. Thus, tensile strengths of the material in the vertical direction are very low.

One boring, U2, was drilled to a depth of 150 feet. The somewhat erratic variation of material type and composition properties extended to a depth of about 70 feet where a more uniform fine-grained sandstone of a lower dry density, i.e., 120 pcf, was encountered. This material is believed to be from the Wingate Formation. Because the samples were air-dried, no information on the in situ water content could be obtained for this material.

In June 1972, the plan for grading along the main WES gage line was received. It called for cut and fill in such a manner that the overburden thickness would be approximately 5 feet along the entire line. The density and water content of the fill were specified to match the in situ condition of the soil at a depth of 2-1/2 feet. Field density data obtained in June and July 1972 indicated that the average wet density and water content were 111 pcf and 7 percent, respectively. Figure 2.8 is a sketch of the idealized profile along the main WES gage line showing the filled section of varying thickness which was constructed prior to Event III and the underlying nonhomogeneous sedimentary materials.

At the time of Event III, the surface soil at the site was muddy due to wet weather conditions. Water contents were obtained from samples of the fill along the main gage line on the day before and the day after the event. The water contents are plotted versus distance from GZ in Figure 2.9. The results shown in Figure 2.9 indicate that the water content of the near-surface soil increased due to wet weather conditions from a value of about 7 percent as measured during the previous summer (and used to develop the preshot representative properties) to a value of about 15 percent at shot time. NX-size cores of the nearsurface rock were taken at two locations to a depth of approximately 30 feet on the day following Event III. Water content and wet density 
measurements determined from these cores appeared to be within the scatter of the original data, as shown in Figure 2.10. 


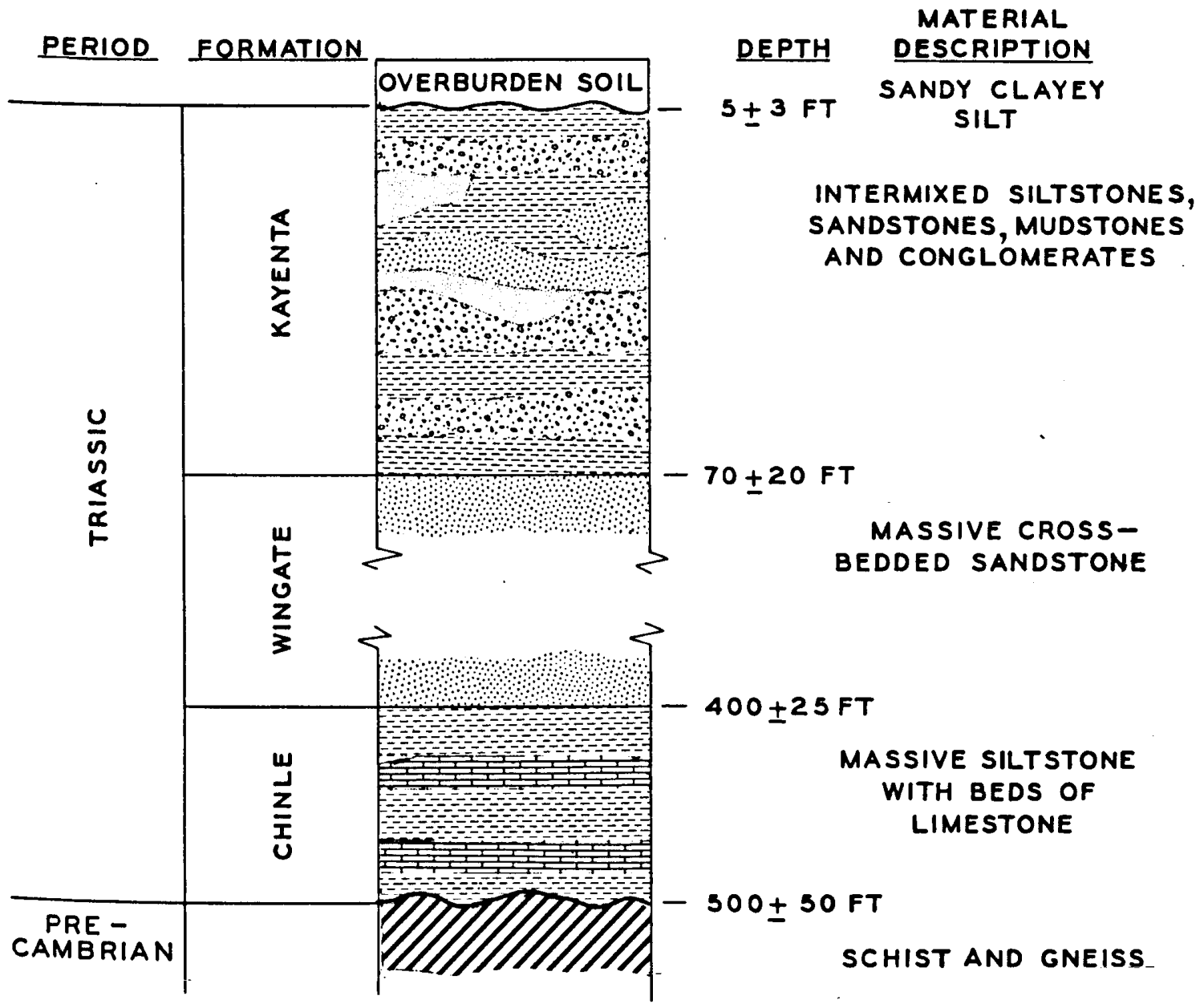

Figure 2.1 Stratigraphy column for Mixed Company site. 


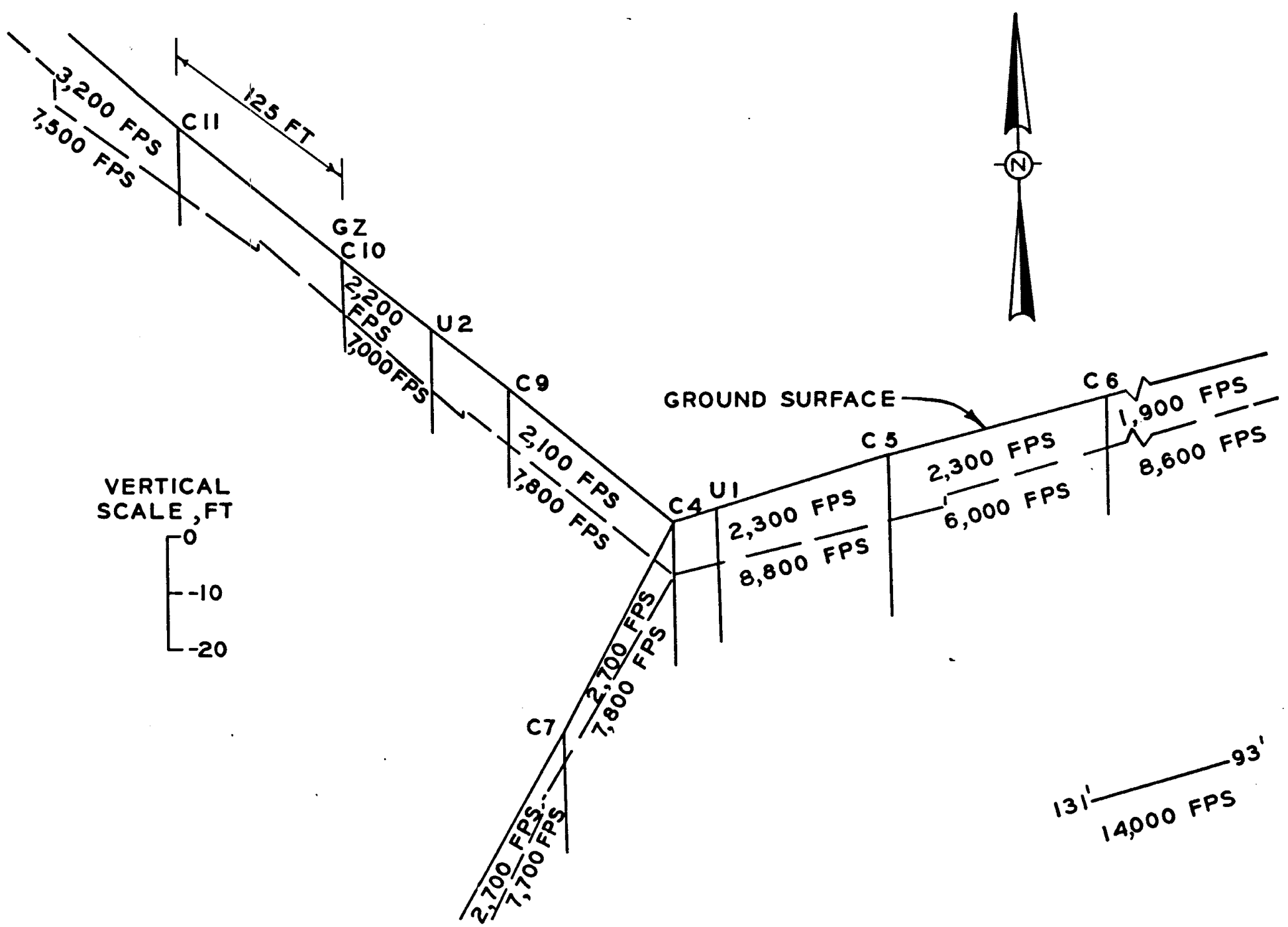

Figure 2.2 Schematic fence diagram along boring lines showing subsurface profile as defined by field refraction seismic survey. 


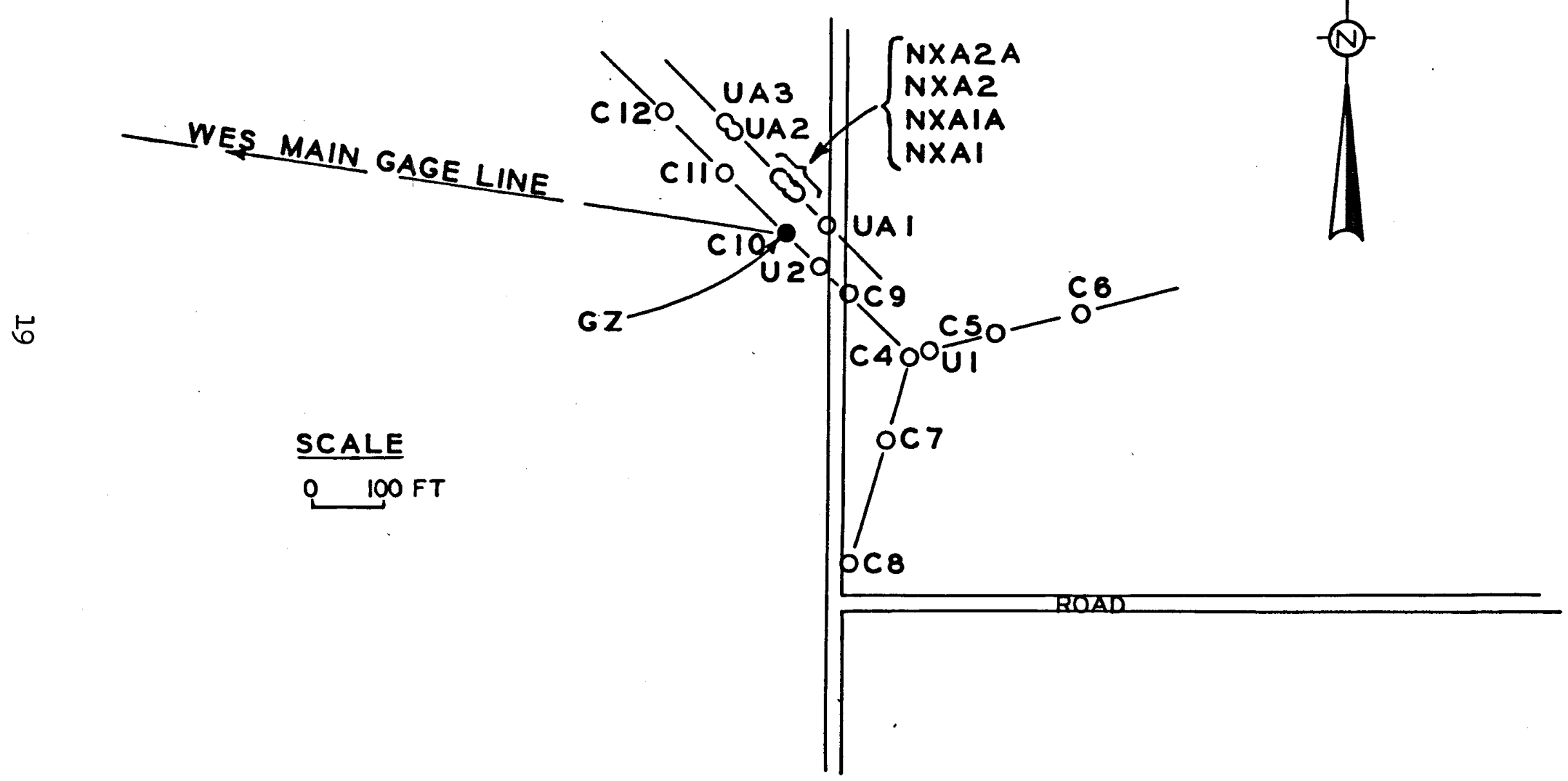

Figure 2.3 Plan view of the Mixed Company Event III site showing boring locations. 


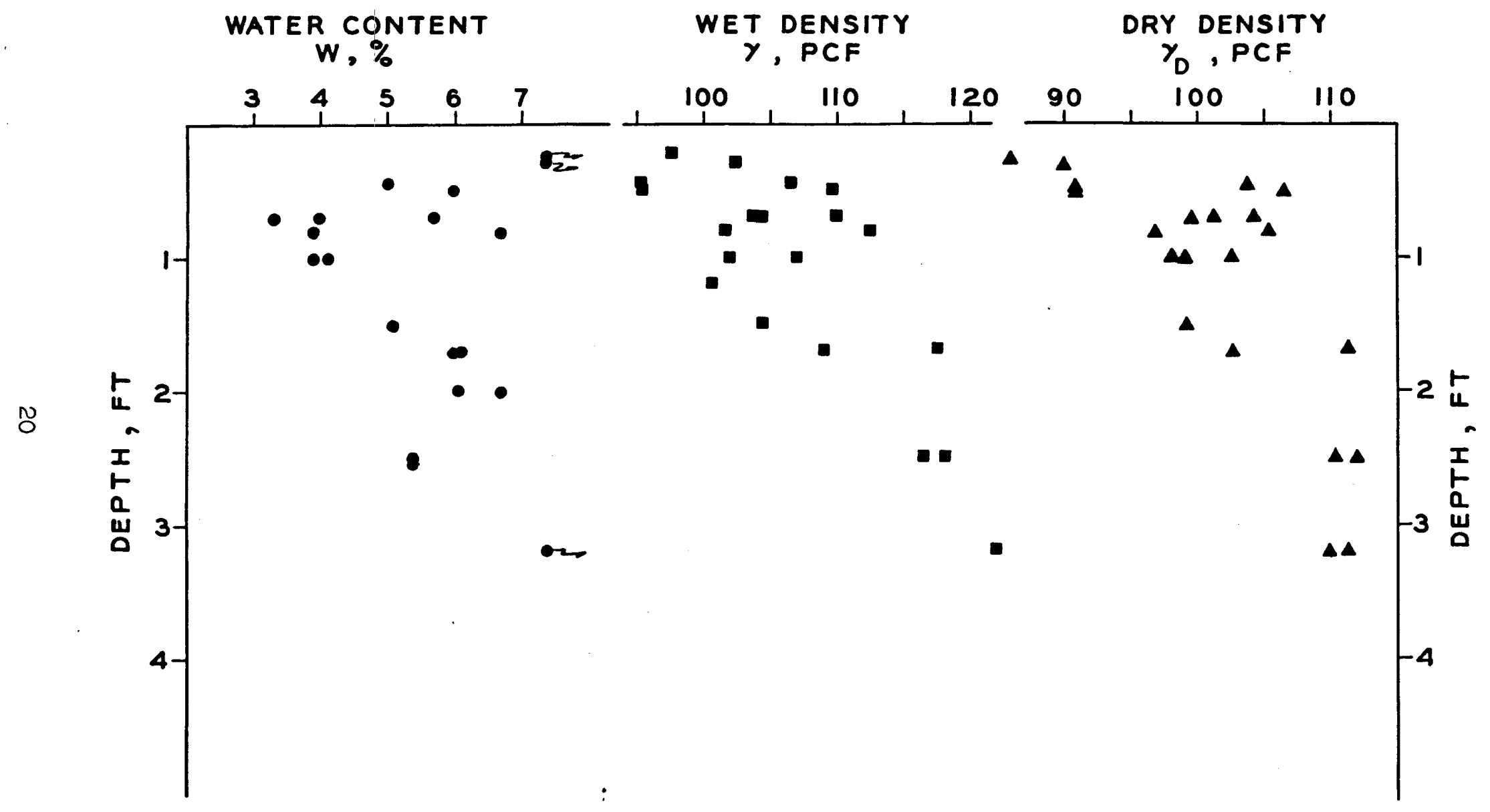

Figure 2.4 Composition properties of overburden soil zone. 


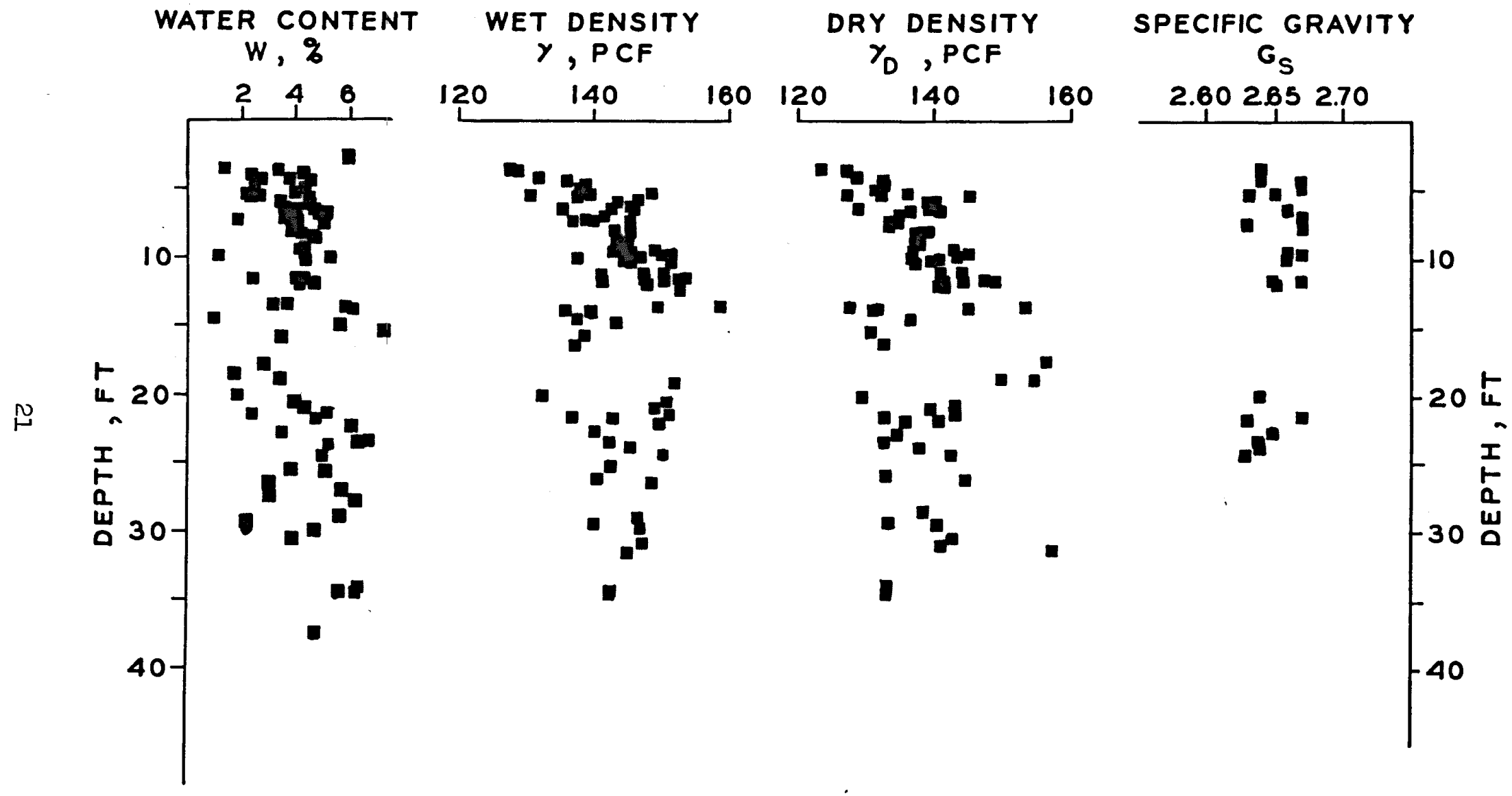

Figure 2.5 Composition properties of Kayenta Formation rocks. 


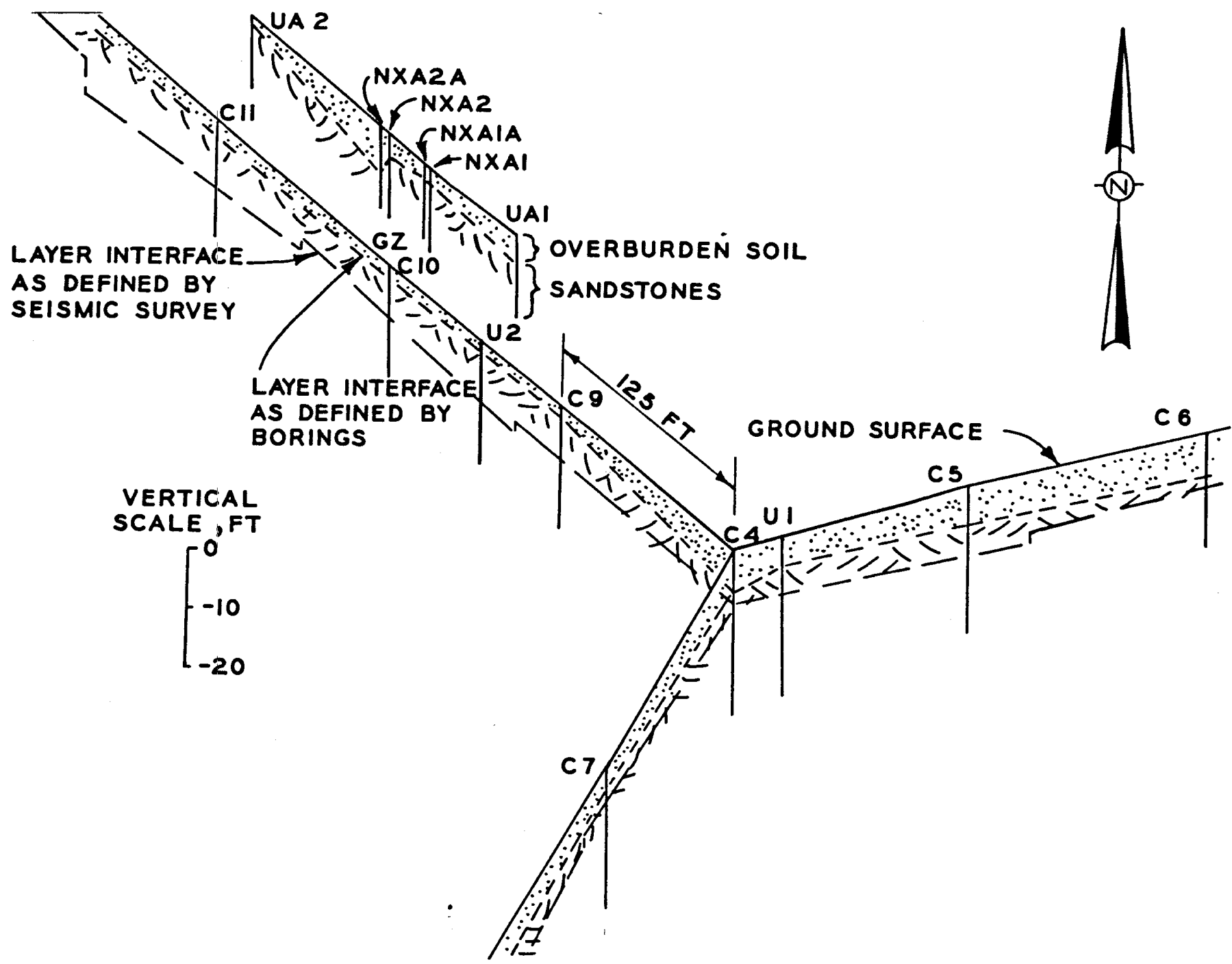

Figure 2.6 Schematic fence diagram showing the soil-rock interface as defined by borings compared with the interface defined by the seismic survey. 


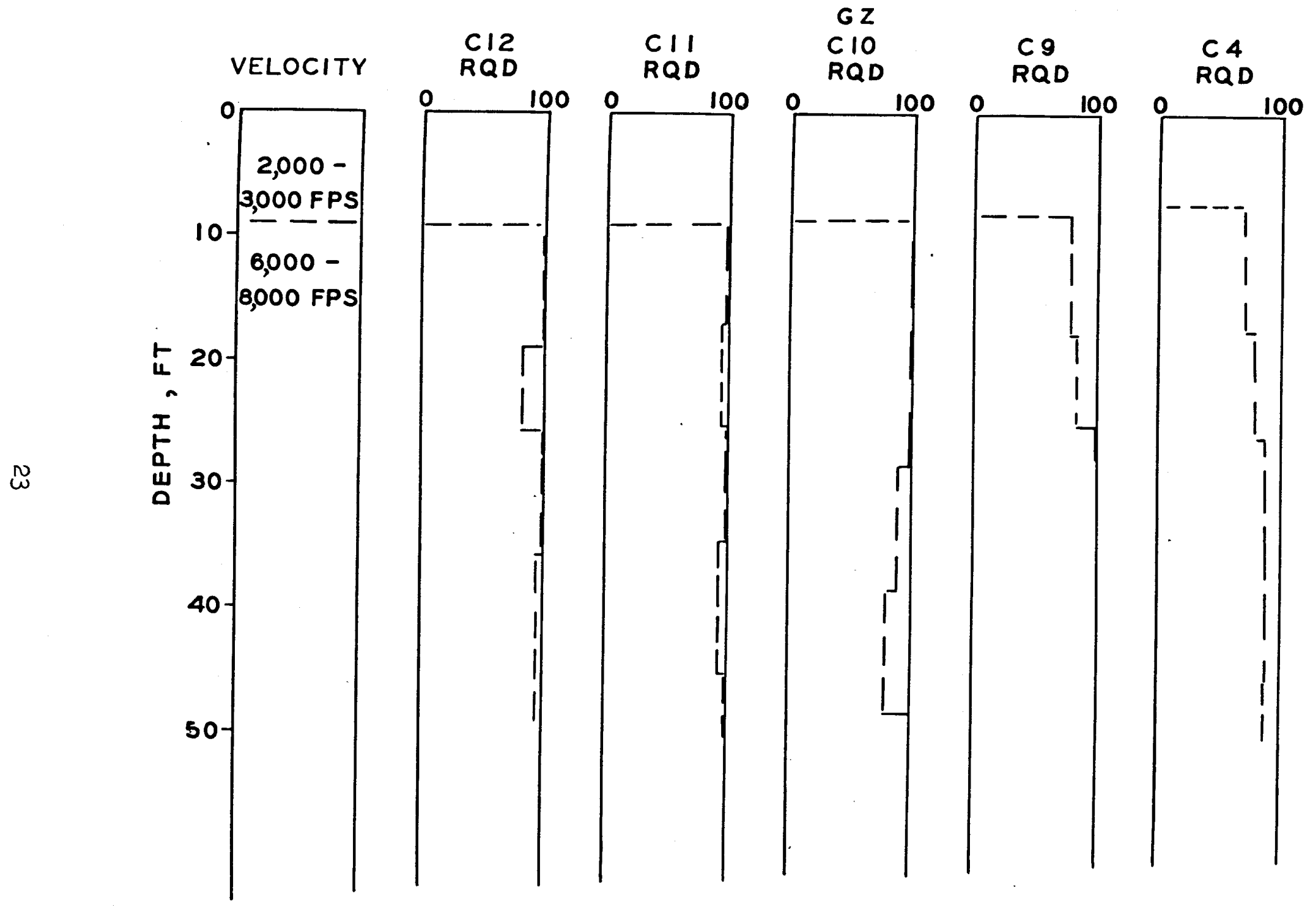

Figure 2.7 Rock quality index (RQD) of several boring compared with field velocity data. 


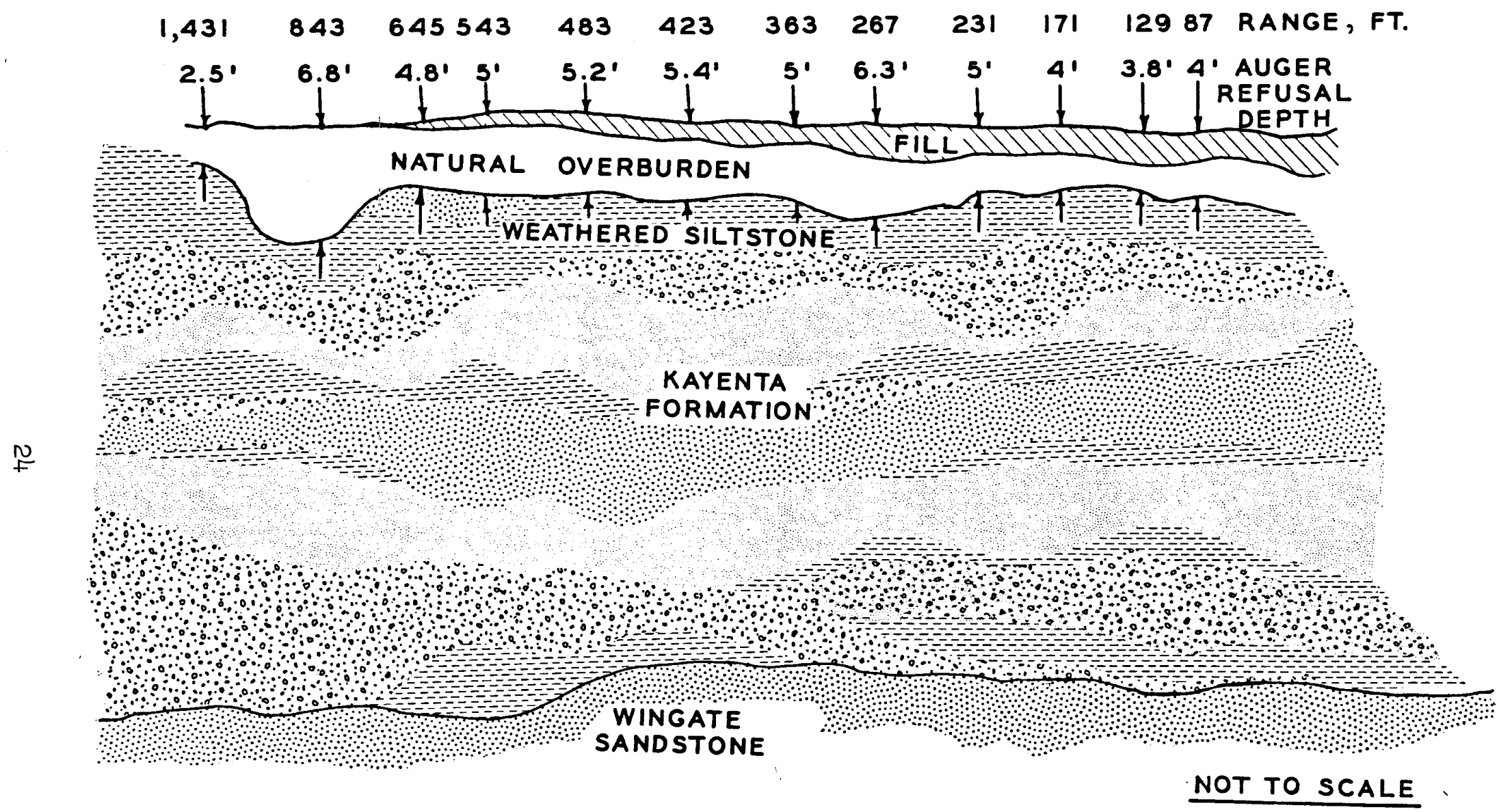

Figure 2.8 Idealized subsurface profile along main gage line indicating variation of materials. 


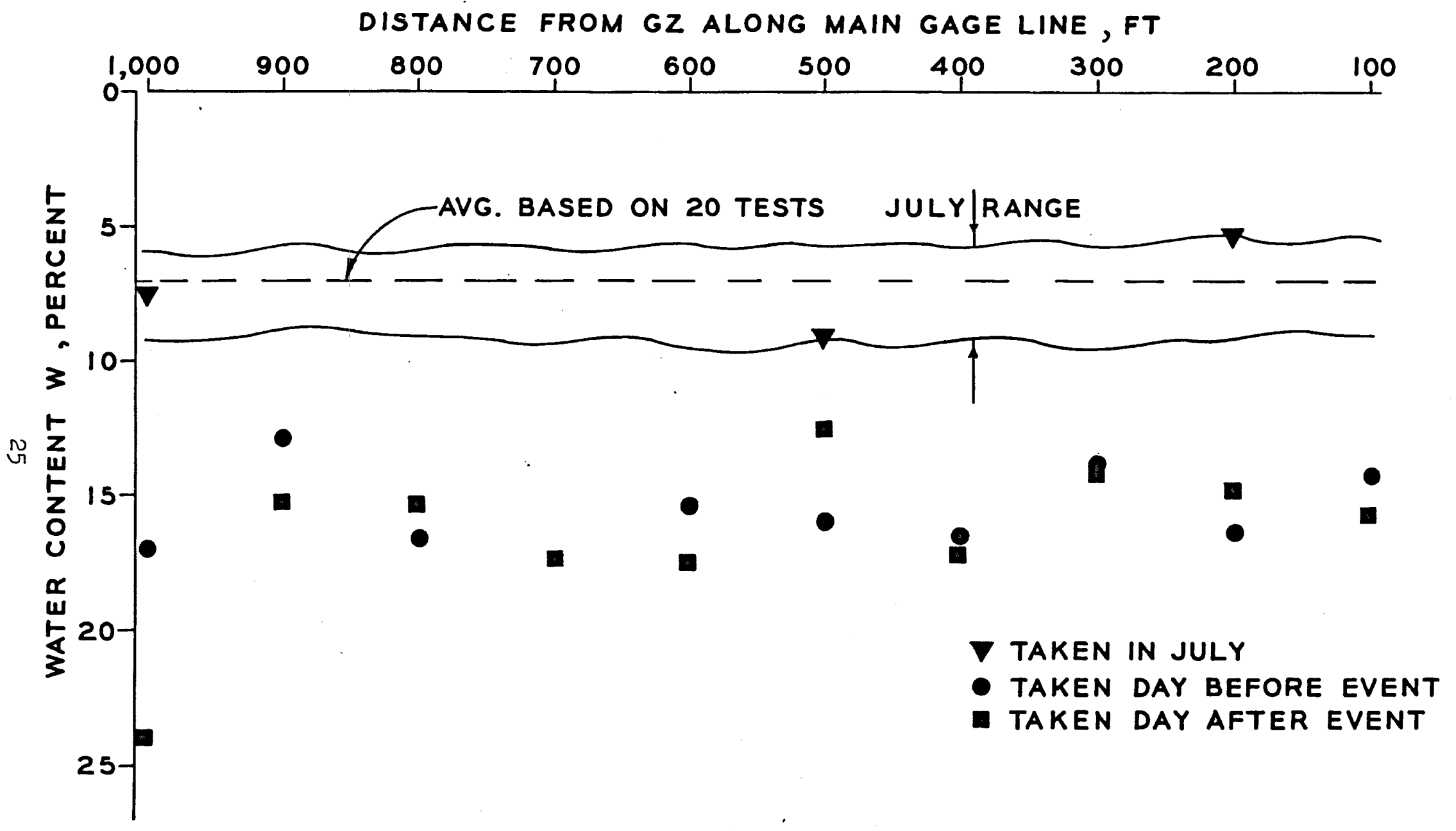

Figure 2.9 Water content of soil taken in July 1972 compared with water contents the day before and the day after Event III. 


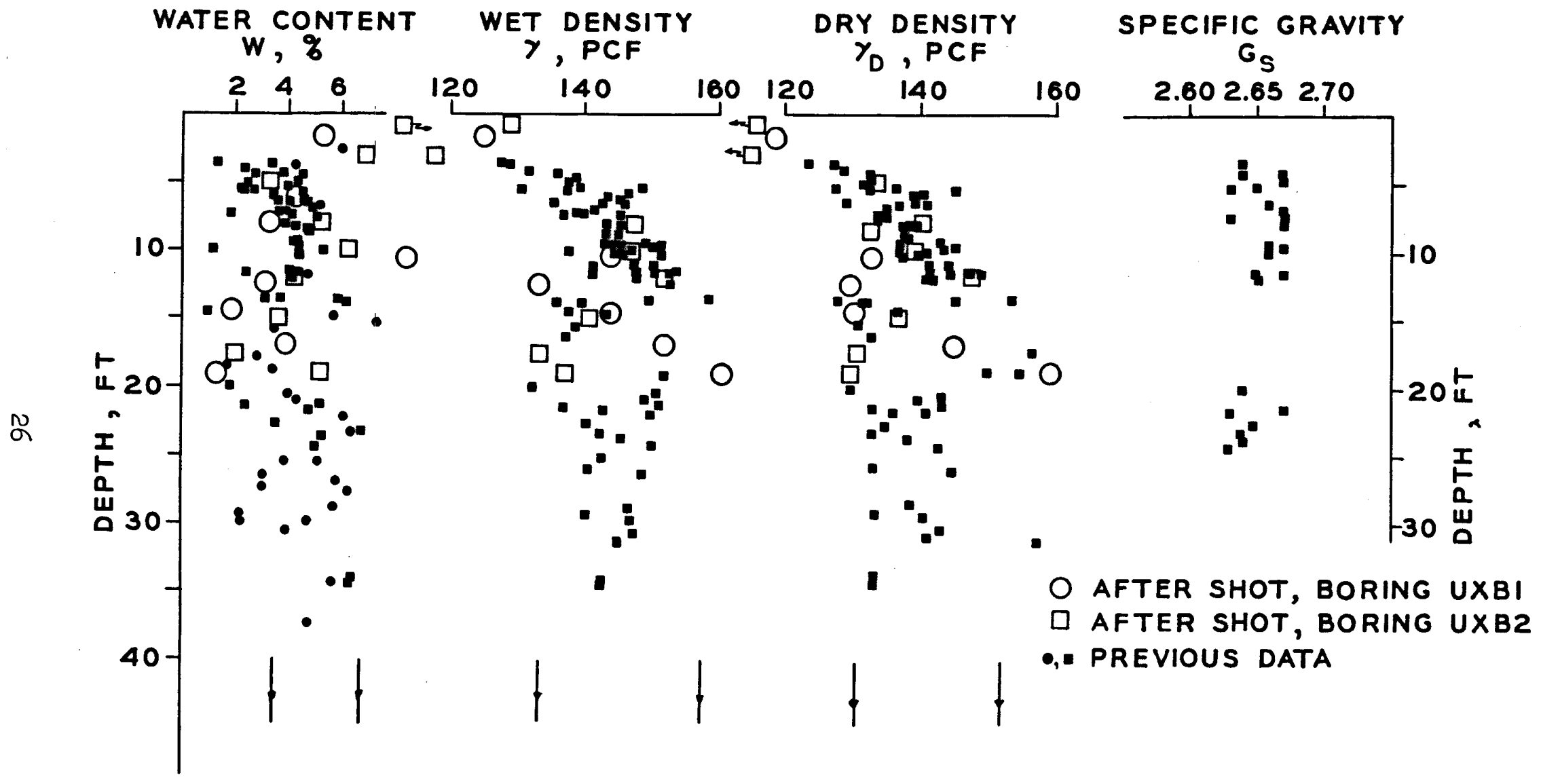

Figure 2.10 Original composition properties of Kayenta Formation and composition properties taken the day after Event III. 


\section{LABORATORY TEST RESULTS}

The objective of the laboratory test program was to investigate the responses of the Mixed Company III materials under several controlled states of stress. The properties were to be used in code calculations of the ground motion along the main WES gage line. Expected peak stress levels of interest in the field event varied from the kilobar range down to tenths of a bar; the response of the material was, therefore, examined over the regime.

Several laboratories participated in the test program. Each examined a given stress range and/or special aspect of the materials' responses. These laboratories were the WES Soils and Pavements Laboratory (S\&PL), the WES Concrete Laboratory (CL), TT, and SRI. Each conducted tests on samples obtained from the borings made in September 1971 and/or February 1972. Two sizes of samples were available: NXdiameter (2-1/8 inch) and 5-inch diameter. Data from the tests conducted on the NX-size samples obtained in September 1971, however, were considered suspect since, as previously mentioned, those samples were air-dried in the field.

Since the purpose of this chapter is to present an overview of the results, data will be presented only to illustrate typical static and dynamic stress-strain response characteristics of the overburden and of the rock. The entire body of test data will be documented later.

\subsection{TESTS}

The tests conducted were grouped into four classes: (1) uniaxial strain (UX), (2) isotropic compression (IC), (3) triaxial shear (IX), and (4) tension tests. Three types of UX tests (i.e., radial strain, $\epsilon_{r}=0$ ) were conducted: (1) gas or powder gun tests by CL and SRI in which a very thin wafer specimen was loaded by a flat-ended projectile with microsecond range loading rates to obtain stress-particle velocity relations, (2) tests by S\&PL in which a 1- or 2.5-inch-high by 5-inchdiameter specimen was loaded by fluid pressure within loading rates 
ranging from several milliseconds (dynamic) to several minutes (static) to obtain stress-strain relations, and (3) tests by S\&PL, CL, and TT on cylindrical specimens statically loaded in the vertical direction through steel end caps while a circumferential or radial fluid pressure was applied to the specimen to restrain radial movement (detected by a sensor). This particular type of UX test is frequently referred to as a $\mathrm{K}_{\mathrm{o}}$ test and yields both axial stress-axial strain and axial stressradial stress relations.

The IC tests by S\&PL, CL, and TT were conducted on cylindrical specimens loaded by a uniform all-around pressure to obtain pressurevolumetric strain relations. TX tests by S\&PL, CL, and TT were conducted immediately following the loading phase of the IC tests. The hydrostatic pressure was held constant and the vertical axial load was increased until shear failure occurred. From the TX tests, stress difference-strain difference or stress difference-axial strain relations were obtained. The tensile tests by CL were conducted on cylindrical specimens either by direct pull along the vertical axis or by a line loading applied along the sides of the specimens. This latter type tension test is referred to as a Brazil test. In all of the tests, the specimens remained undrained during loading.

Table 3.1 presents a summary of the laboratory test program; it lists the performing laboratory, the type of test, the stress or pressure range investigated, the type material, and the approximate number of tests conducted. Included in the list are only those tests which were conducted prior to June 1972 and whose results were available for the development of the preshot constitutive property recommendations.

\subsection{OVERBURDEN SOIL}

The Mixed Company soil was classified as a sandy clayey silt (ML) in accordance with the Unified Soil Classification System. Since fill was to be added along the gage line and since the natural and fill overburden were to be confined into a single layer in the $2 \mathrm{D}$ calculations, response of this layer would be a function of the properties of both the natural soil and the compacted fill. Therefore, the soil was tested 
in both the undisturbed condition and after it had been remolded to a range of densities and water contents. ${ }^{1}$ The tests on the soil consisted of UX, IC, and TX tests. Figure 3.1 shows a plot of axial stress versus axial strain for several UX tests on the remolded soil at various densities. In general, the loading stress-strain curve stiffened with increasing density at a constant water content and the initial modulus softened with increasing water content at constant density.

The material indicated a strain-hardening response in shear with compaction occurring under low confining pressure (0 to 2,000 psi). The TX failure strength increased with increasing confining pressure. Some rate effects were noted, but they appeared to be masked by the effects due to the natural variation in density. Nevertheless, UX and TX tests with millisecond loading rates rather than static loading rates were used as the primary basis for development of representative properties since millisecond-range loading times were expected to occur in the actual field event.

\subsection{WEATHERED SILTSTONE}

Only a limited number of laboratory tests were conducted on specimens from the weathered siltstone zone due to the broken or laminated condition of the core. Most of the NX-size core pieces from this zone were less than 2 inches long and could be used only for water content and density measurements. UX tests were conducted on the 5-inchdiameter, Shelby-tube-encased samples. The steel tubes were first $\mathrm{X}$-rayed in an attempt to locate horizontal separations. Attempts were then made to obtain intact 1 -inch- or 2-1/2-inch-long specimens. It was found that even with the use of this procedure, many of the specimens contained open horizontal laminations or planes of weakness. One 2-1/2-inch-long specimen which appeared to be in good condition separated during handling. The exposed faces contained an intricate root

1 Since the field backfill density and water content had not been specified at the time of testing, a range of probable values had to be investigated. 
system resembling a loosely woven piece of cloth. As a result, most of the UX specimens tested strained several percent in the vertical direction under very low stress levels (i.e., less than $10 \mathrm{psi}$ ). Above these levels, the UX curves stiffened gradually to approximately 1,000 psi, and thereafter a marked stiffening of the stress-strain curves occurred. Unloading moduli were quite stiff, resulting in significant hysteresis or inelastic response.

Several TX tests were conducted on specimens obtained from near the bottom of the weathered zone; results of these tests were similar to those of tests on specimens of the deeper sandstones, which will be presented later in this chapter. No direct-pull tension tests were conducted since the material would separate along the laminations under its own weight.

\subsection{UNWEATHERED KAYENTA MATERTALS}

The fact that a large variety of sandstones, siltstones, conglomerates, and mudstones appeared to occur randomly with depth within the Kayenta Formation made it desirable that a number or UX and TX tests be conducted on each material encountered if a reasonably accurate understanding of the overall behavior of the composite mass was to be achieved. Unfortunately, it was not possible to obtain representative test specimens in all caises; therefore, parametric studies had to be conducted. For example, since some of the available NX-size cores had been air-dried, it was necessary to determine the effects of water content variations on the UX and TX behavior. In addition, static and dynamic UX, IC, and TX tests were conducted to determine sensitivity to loading rate effects.

3.4.I UX Gun Tests. Gas or powder gun tests were conducted on both wet and dry specimens from the Kayenta Formation. Although most of the testing was limited to the better quality sandstones, some tests were performed on other materials. Attempts were also made to replace water loss during specimen preparation. Typical test results, as shown in Figure 3.2, indicated a stiff initial stress-strain relation, followed by a softening associated with structural collapse of the cemented 
grains. The level of the softening or collapse varied from 4 to $6 \mathrm{kbar}$. This limited data did not indicate a difference in the stress level associated with collapse between the dry specimens and the partially saturated specimens. However, scatter in the gun test data was noted, but it appeared to be due to differences between the various test specimens in lithology and density. Two tests were conducted on similar airdried specimens at stress levels above $20 \mathrm{kbar}$, and these results are also shown in Figure 3.2. The data indicated a stiffening at strain levels approximately equal to the volume percentage of air $\mathrm{V}_{\mathrm{a}}$ within the specimen. The inserts shown in Figure 3.2 indicate different possible interpretations of the data with regard to the unloading path from those stress levels.

3.4.2 UX Tests on 5-Inch-Diameter Specimens. Both static (several minutes to peak stress) and dynamic (several milliseconds to peak stress) tests were conducted. No differences greater than the general data variation or scattering for a given material were noted between the data from dynamic tests and the data from static tests. Although most of these tests were conducted on specimens with preserved in situ water contents, tests were also conducted on laboratory air-dried specimens and on specimens which were rewetted after first being air-dried. The results did not indicate effects greater than the general data variation.

UX tests to $200 \mathrm{psi}$ were conducted to examine the initial loading moduli and the unloading response at low stress levels. Results, such as those shown in Figure 3.3, did not, in general, correlate well with the initial moduli associated with the field seismic velocity. However, they did indicate a significant hysteretic behavior of the materials even when unloading occurred from these low pressures.

Figure 3.4 shows typical UX stress-strain results from some of the 2,000-psi-level tests on the Kayenta materials from shallow (<25 feet) depths; typical results from the overlying weathered siltstone are shown for comparison. Because all of the lithologies encountered in the upper Kayenta Formation are represented in the Figure 3.4 test 
results, which include results of tests on weathered specimens, the data scatter is quite large.

Stress-strain curves from four selected 8,000-psi-level UX tests, which bound all the 2,000-psi data shown in Figure 3.4, are shown in Figure 3.5. As in the case of the 2,000-psi-level results, the scatter in these higher stress level tests is also primarily a function of change in lithology and weathering. Again, it was not possible to establish a definite effect due to the loading rate effect between the dynamic (ten milliseconds to peak) and static tests on similar materials.

3.4.3 UX $\mathrm{K}_{\mathrm{O}}$ Tests. Static $\mathrm{K}_{\mathrm{O}}$ tests were conducted to determine the stress path response (principal stress difference versus mean normal stress) of the material. Peak stress levels ranged from about 0.1 to $4 \mathrm{kbar}$. The data indicated a low initial Poisson's ratio which increased slightly with stress. A marked decrease in the stress path slope (signifying a marked increase in Poisson's ratio) was noted at the 2- to 3-kbar principal stress difference level. This stress difference level is in general agreement with that at which structural collapse was observed in the UX gun test data. At higher stress differences, the stress path curvature reversed, i.e., the slope increased again, thereby indicating a decrease in Poisson's ratio. Figure 3.6 shows the $K_{0}$ stress path data generated by TT and a typical representative UX stress path relation derived from them.

3.4.4 IC and TX Tests. Most of the IC tests were conducted as the confining pressure application phase of $T X$ tests and were, therefore, really one part of a two-part test. Both static and dynamic IC tests were conducted to 8,000 psi and static tests were conducted at pressures up to $4 \mathrm{kbar}$. The general shapes of the pressure-volumetric strain curves were similar to those of the axial stress-axial strain curves from the UX tests. Figure 3.7 shows results of static and dynamic tests on sandstones from shallow ( $<25$ feet) depths; it indicates approximately the same range of scatter in both static and dynamic loadings as was noted in the UX tests on similar materials. The IC tests to 4 kbar yielded pressure-volumetric strain curves which 
continued to stiffen with increasing pressure, i.e., no structural collapse or softening of the pressure-volumetric stress relation was observed up to 4 kbar. The fact that collapse occurred during the UX loading at these stress levels and did not occur under hydrostatic loading indicates a dependence of the collapse phenomena on principal stress difference or shear stress.

A series of static and dynamic TX tests were conducted at confining pressures up to 6,000 psi. The principal stress difference versus axial strain relation indicated a dependence on confining pressure prior to failure; the failure strength of all materials increased with increasing confining pressure. Axial strains at failure for most of the Kayenta materials were on the order of $I$ percent when tested under confining pressures less than 6,000 psi. However, a much softer response (i.e., greater strains) was noted on a clayey conglomerate found near the 20-foot depth. Figure 3.8 is a plot of principal stress difference versus axial strain showing representative dynamic shear test data for most of the materials tested including the clayey conglomerate.

A series of static TX tests was also conducted at confining pressures of 2 to $4 \mathrm{kbar}$. The initial loading moduli from these high confining pressure tests were similar to those in the lower pressure tests, and the failure strengths continued to increase with increasing confining pressures. But the strains at which failure occurred were significantly greater for the high-pressure tests, i.e., failure occurred at 5 to 10 percent axial strain, whereas in the lower confining pressure tests, failures generally occurred at about $I$ percent axial strain. Volumetric strain changes of the sandstones during shear were also observed during the testing. Although some compaction was noted during initial loading, at stress states near failure, the material dilated as shown in Figure 3.9. Upon loading, volumetric strain tended to reverse and recompaction occurred. After removal of shear loading, the unloading portions of the pressure-volumetric strain curves that were generated as the mean normal stress was subsequently removed were similar to the unloading curves from IC tests without follow-on TX shear phases. The dashed lines in Figure 3.9 are for clarity only. 
The TX failure envelopes obtained for the sandstones showed surprisingly little variation considering the wide variation noted in UX and IC test data. Figure 3.10 is a plot of both static and dynamic failure data on sandstones from depths less than 25 feet. Several tests conducted at other than constant confining pressure conditions indicated that the strength of the material was independent of the loading path loading to failure.

3.4.5 Tension Tests. "Two types of tension tests were conducted on the sandstones, i.e., direct-pull and Brazil tests. The direct-pull tests were conducted on a limited number of NX-size specimens which were oriented with their axis of symmetry in the vertical direction. Most of the failure stresses were less than $100 \mathrm{psi}$, and many specimens fell apart under their own weight along thin horizontal clay seams of laminations. The Brazil tests were conducted by applying a line load along the sides of a number of NX-size core pieces. There is some question as to the actual validity of the tests results, but it was felt that they could provide an index to the tensile strengths of the materials. Failure stresses as high as 500 psi were measured. Although the exact stress levels may be questionable, the results do indicate that the materials encountered have a substantially higher tensile strength in the horizontal direction than in the vertical direction. 
TABLE 3.1 SUMMARY OF LABORATORY TEST PROGRAM

\begin{tabular}{|c|c|c|c|c|}
\hline Laboratory & Type of Testa & Pressure Range & $\begin{array}{l}\text { Type } \\
\text { Material }\end{array}$ & $\begin{array}{l}\text { Approximate } \\
\text { No. of Tests }\end{array}$ \\
\hline \multirow[t]{5}{*}{ WES S\&PL } & $\begin{array}{l}\text { Static and dynamic } \mathrm{UX} \\
\text { Static and dymamic } \mathrm{TX} \\
\text { Static } \mathrm{K}_{\mathrm{o}}\end{array}$ & $\begin{array}{l}\text { Axial stresses to } 10,000 \text { psi } \\
\text { Confining pressures to } 6,000 \text { psi } \\
\text { Mean pressures to } 2,000 \text { psi }\end{array}$ & $\begin{array}{l}\text { Undisturbed and } \\
\text { remolded soil }\end{array}$ & $\begin{array}{r}22 \\
37 \\
7\end{array}$ \\
\hline & $\begin{array}{l}\text { Static and dymamic UX } \\
\text { Static and dynamic UX } \\
\text { Static and dymamic UX }\end{array}$ & $\begin{array}{l}\text { Loaded to } 200 \text { psi, unloaded, and } \\
\text { reloaded to } 2,000 \text { psi } \\
\text { Axial stresses to } 2,000 \text { psi } \\
\text { Axial stresses to } 10,000 \text { psi }\end{array}$ & $\begin{array}{l}\text { Rock } \\
\text { Rock } \\
\text { Rock }\end{array}$ & $\begin{array}{l}30^{b} \\
10 \\
19\end{array}$ \\
\hline & $\begin{array}{l}\text { Static and dynamic IC } \\
\text { Static and dynamic TX }\end{array}$ & $\begin{array}{l}\text { Mean pressures to } 8,000 \text { psi } \\
\text { Confining pressures to } 6,000 \text { psi }\end{array}$ & $\begin{array}{l}\text { Rock } \\
\text { Rock }\end{array}$ & $\begin{array}{l}50 \\
43^{c}\end{array}$ \\
\hline & Static $\mathrm{K}_{\mathrm{o}}$ & Mean pressures to $2,000 \mathrm{psi}$ & Rock & 16 \\
\hline & $\begin{array}{l}\text { Special stress } \\
\text { path tests }\end{array}$ & Mean pressures to $10,000 \mathrm{psi}$ & Rock & 10 \\
\hline \multirow[t]{3}{*}{ WES CL } & $\begin{array}{l}\text { Static IC } \\
\text { Static TX } \\
\text { Static } K_{0}\end{array}$ & $\begin{array}{l}\text { Mean pressures to } 2,000 \text { psi } \\
\text { Confining pressures to } 2,000 \text { psi } \\
\text { Mean pressures to } 30,000 \text { psi }\end{array}$ & $\begin{array}{l}\text { Rock } \\
\text { Rock } \\
\text { Rock }\end{array}$ & $2_{2}^{5}$ \\
\hline & Static tension & Loaded to failure & Rock & 23 \\
\hline & $\begin{array}{l}\text { UX powder gun } \\
\text { UX gas gun } \\
\text { UX powdẹr gun }\end{array}$ & $\begin{array}{l}\text { Loaded to } 70 \text { and to } 90 \mathrm{kbar} \\
\text { Loadings from } 5 \text { to } 10 \mathrm{kbar} \\
\text { Loaded to } 30 \text { and to } 55 \mathrm{kbar}\end{array}$ & $\begin{array}{l}\text { Remolded soil } \\
\text { Rock } \\
\text { Rock }\end{array}$ & $\begin{array}{r}2 \\
10 \\
2\end{array}$ \\
\hline \multirow[t]{2}{*}{$T T$} & $\begin{array}{l}\text { Static IC } \\
\text { Static } \mathrm{IX} \\
\text { Static } \mathrm{IX} \\
\text { Static } \mathrm{K}_{0}\end{array}$ & $\begin{array}{l}\text { Mean pressures to } 4 \mathrm{kbar} \\
\text { Confining pressures of } 2 \text { and } 4 \text { kbar } \\
\text { Confining pressures to } 1 / 2 \mathrm{kbar} \\
\text { Mean pressures to } 4 \mathrm{kbar}\end{array}$ & $\begin{array}{l}\text { Rock } \\
\text { Rock } \\
\text { Rock } \\
\text { Rock }\end{array}$ & $\begin{array}{r}7 \\
14 \\
7 \\
9\end{array}$ \\
\hline & $\begin{array}{l}\text { Special stress } \\
\text { path tests }\end{array}$ & Mean pressures to $4 \mathrm{kbar}$ & Rock & 5 \\
\hline SRI & UX gas gun & Loadings fram 5 to $10 \mathrm{kbar}$ & Rock & 5 \\
\hline
\end{tabular}

${ }^{a} \mathrm{UX}=$ uniaxial strain; $\mathrm{IX}=$ triaxial shear; $\mathrm{K}_{0}=\mathrm{UX}$ test on cylindrical specimen; IC = isotropic compression test.

b Measurement system chariged between loadings.

c Ten of the 43 tests were not conducted to failure.

d Includes three tests with confining pressures of 10,000 psi. 


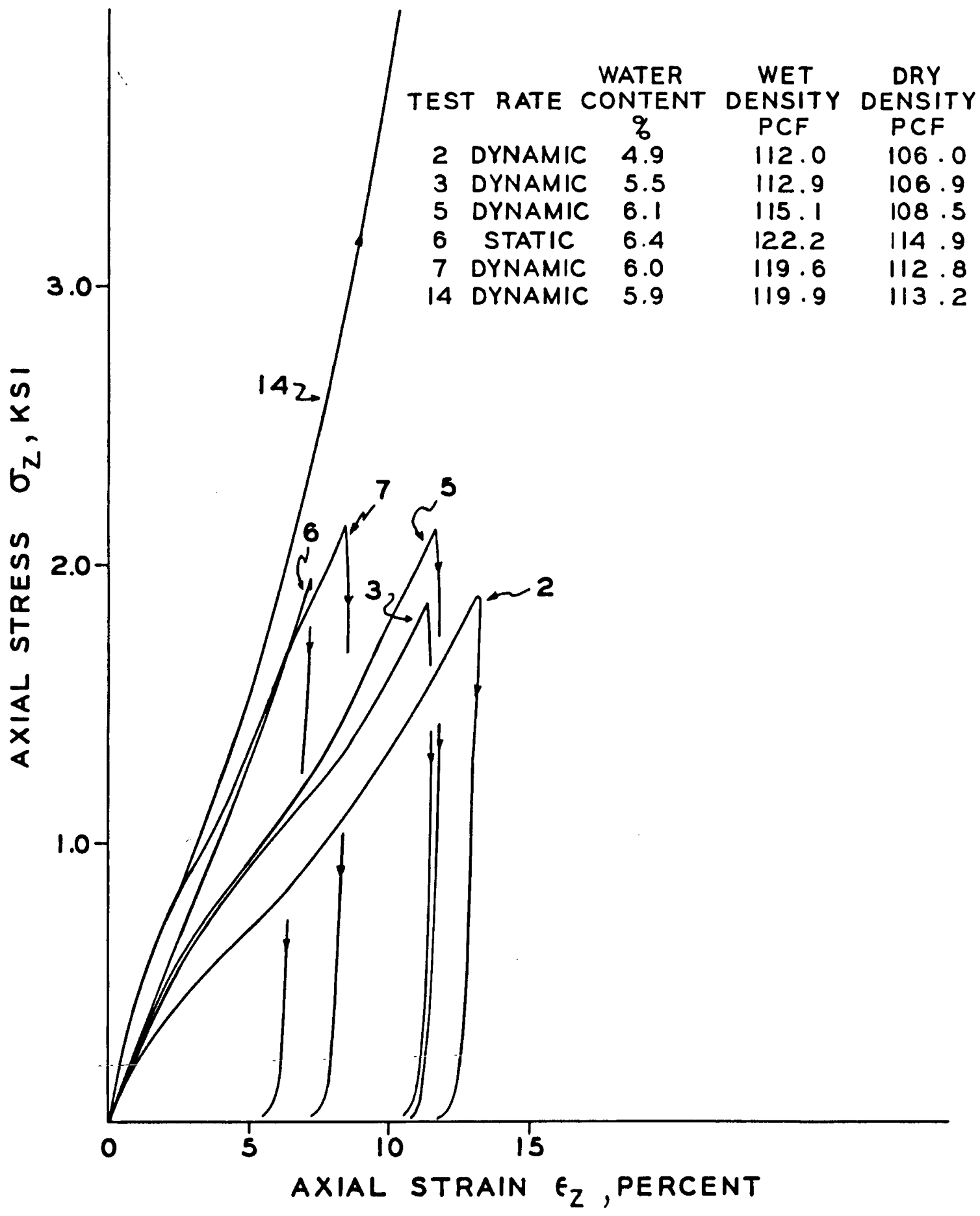

Figure 3.1 Results of UX tests on soil specimens remolded to different densities. 


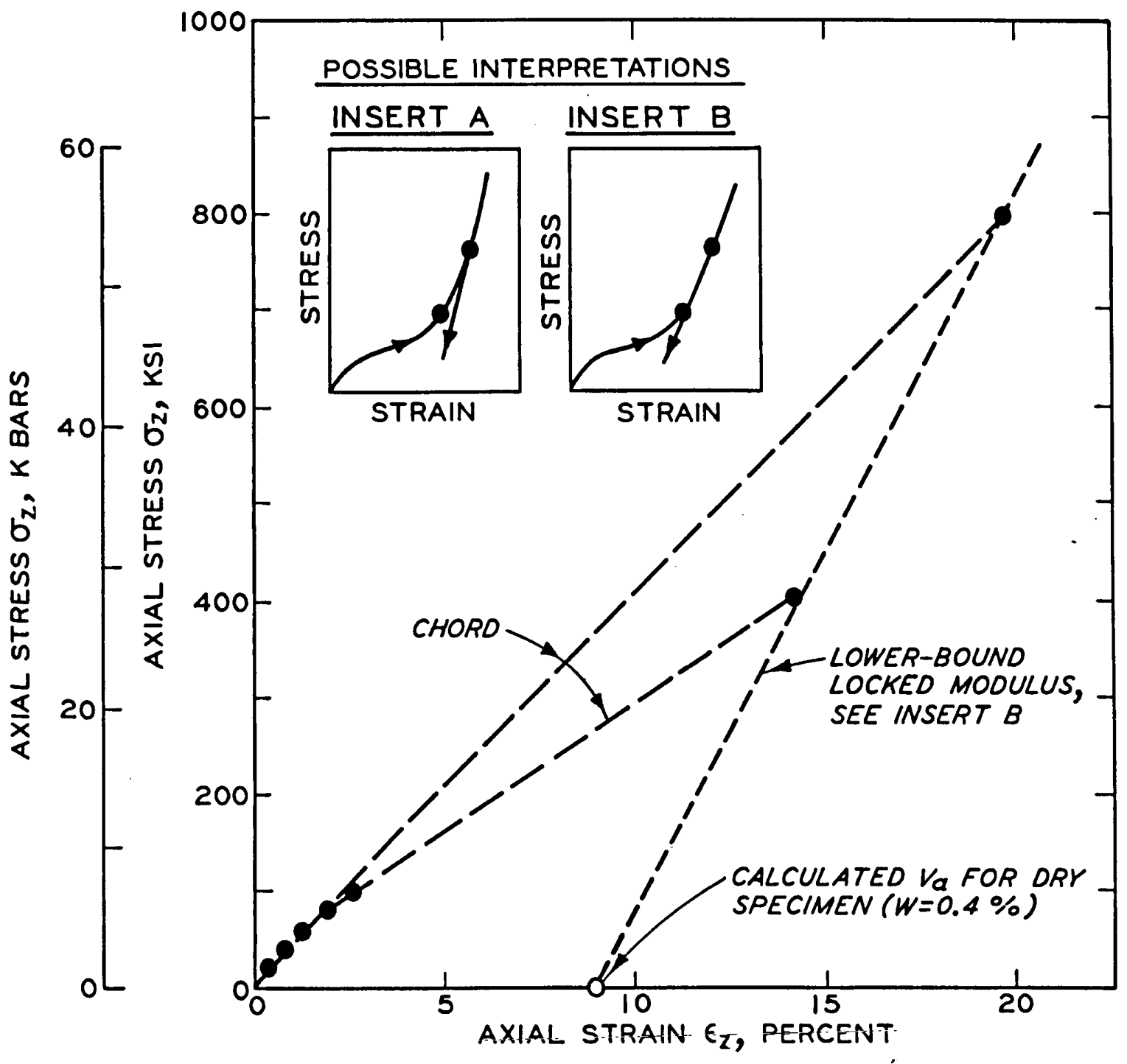

Figure 3.2 Results of UX gun tests showing response of airdried sandstone to high pressures. 


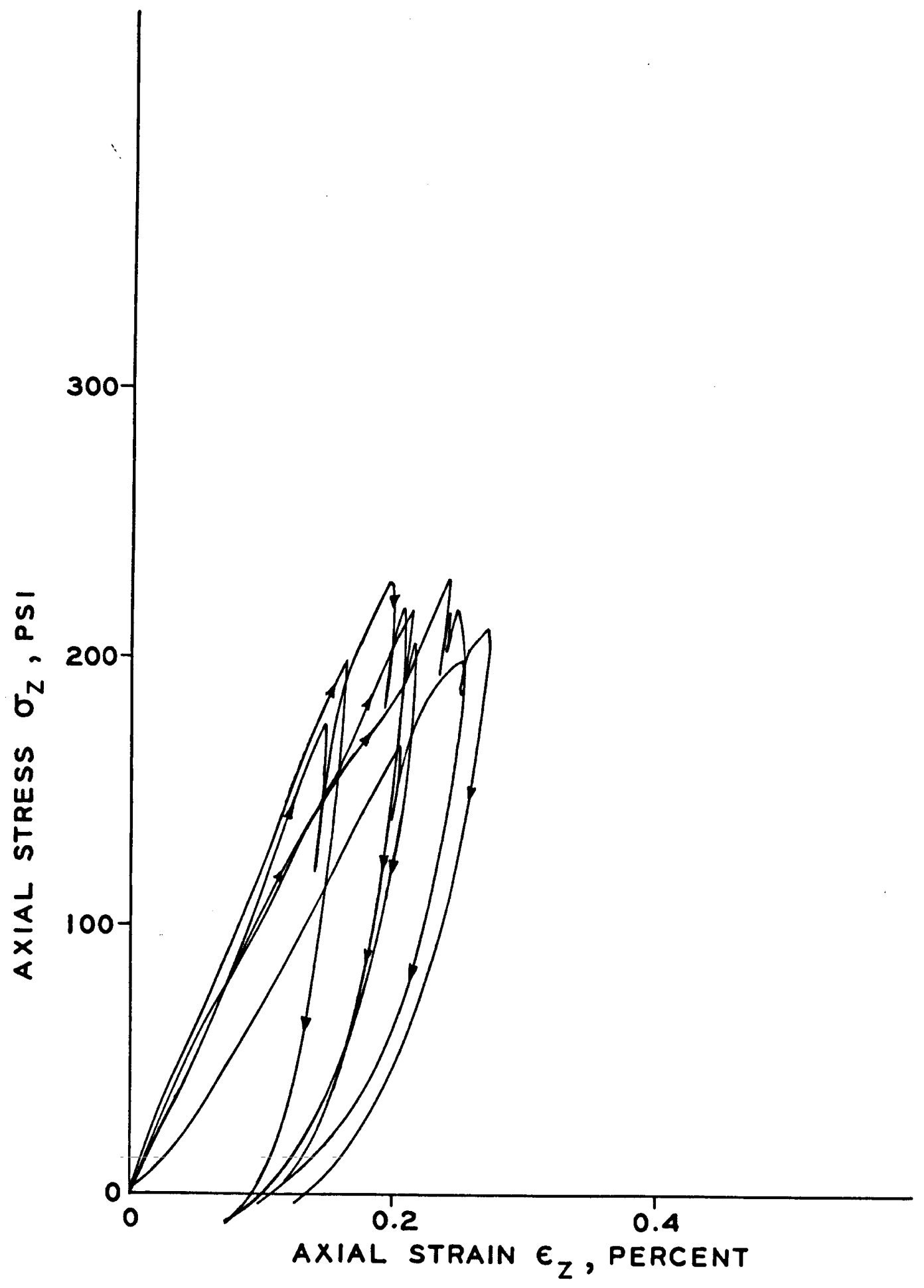

Figure 3.3 Typical dynamic UX test results for shallow (<25 feet) sandstones loaded to 200 psi. 


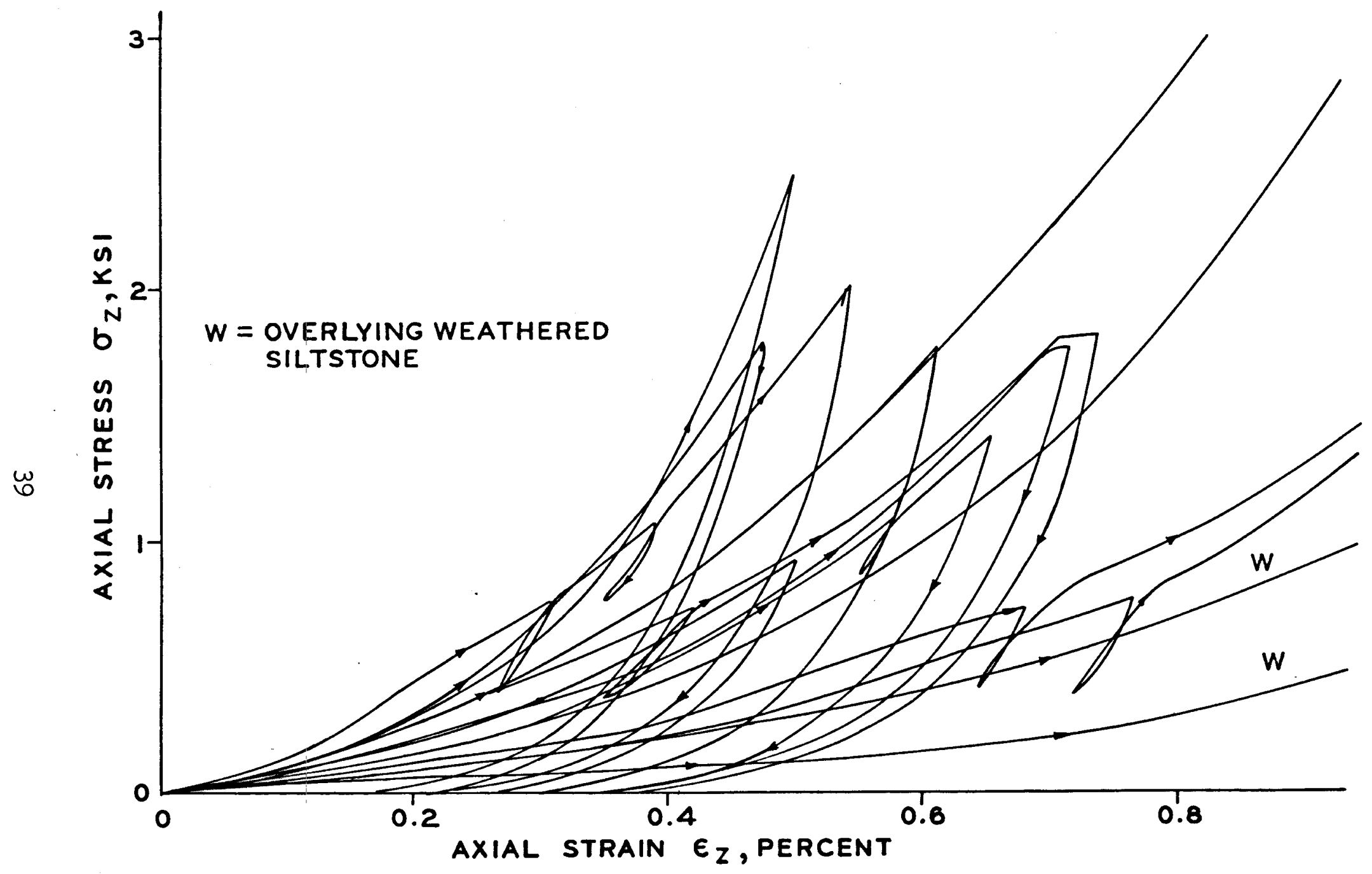

Figure 3.4 Typical dynamic UX test results on Kayenta materials from shallow (<25 feet) depths loaded to 2,000 psi. 


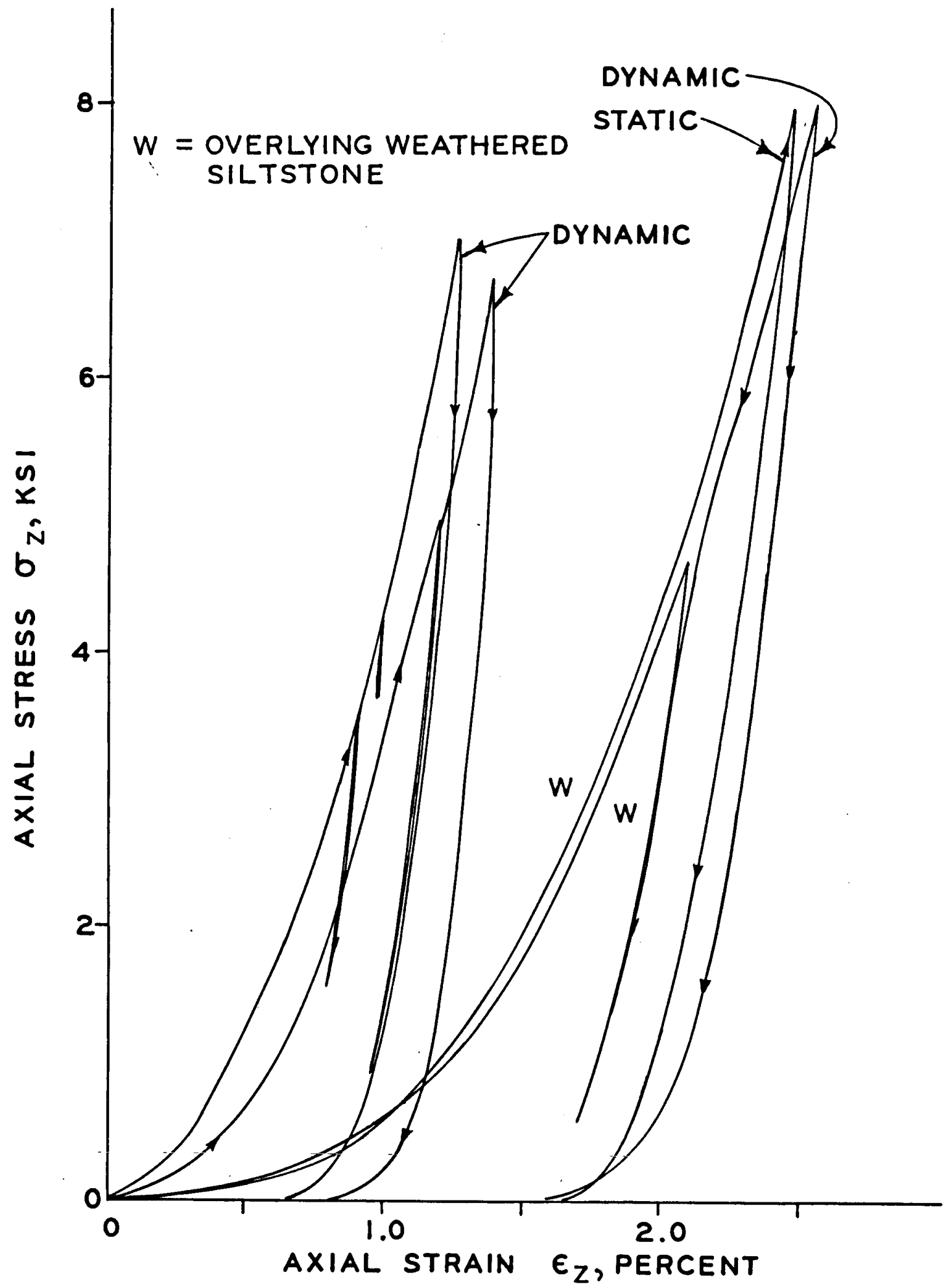

Figure 3.5 Selected dynamic and static UX test results on Kayenta materials from shallow ( $<25$ feet) depths loaded to 8,000 psi. 


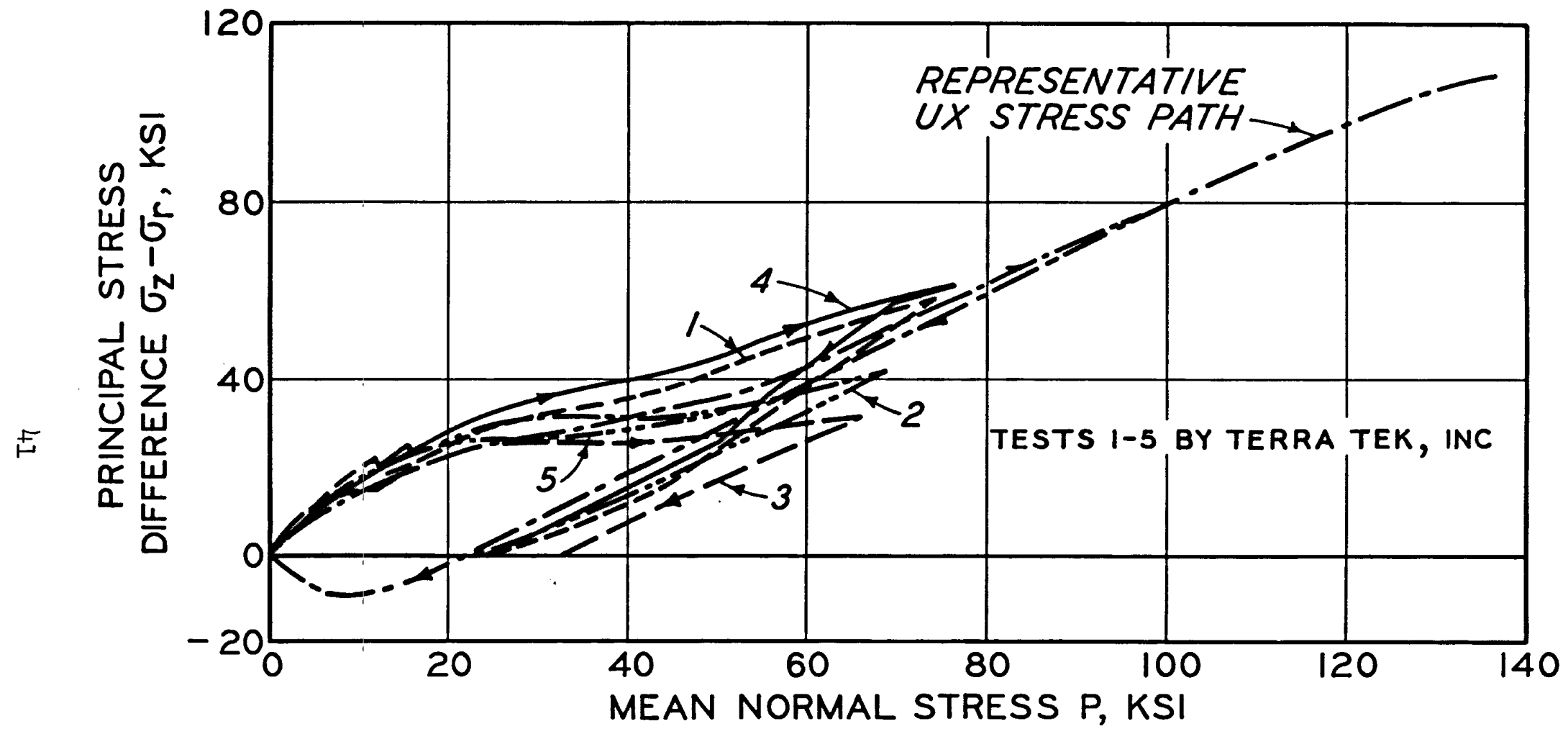

Figure 3.6 Static $K_{0}$ test results on sandstones compared with representative UX stress path response. 


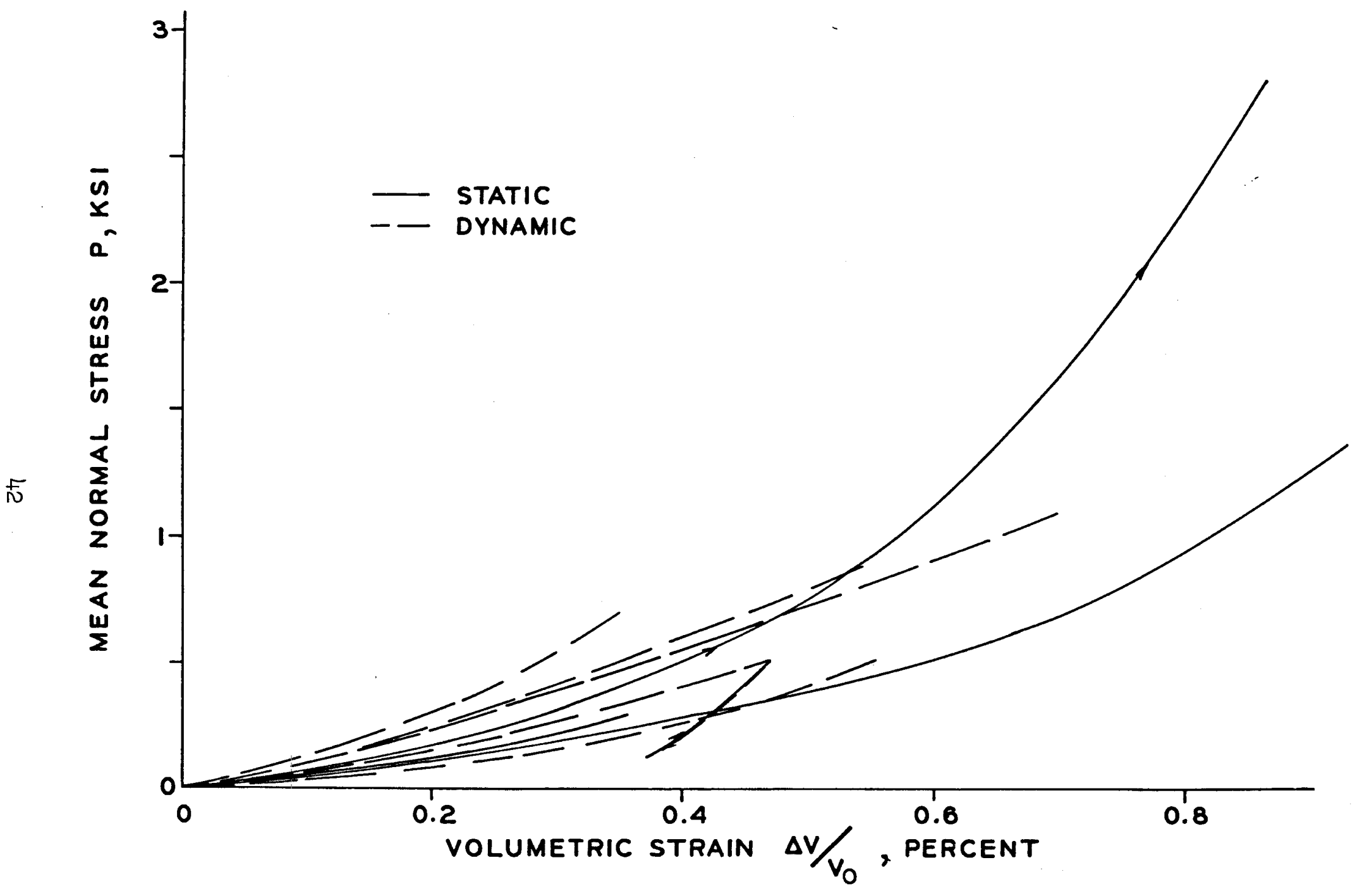

Figure 3.7 Typical static and dynamic IC test results on shallow sandstone ( $<25$ feet). 


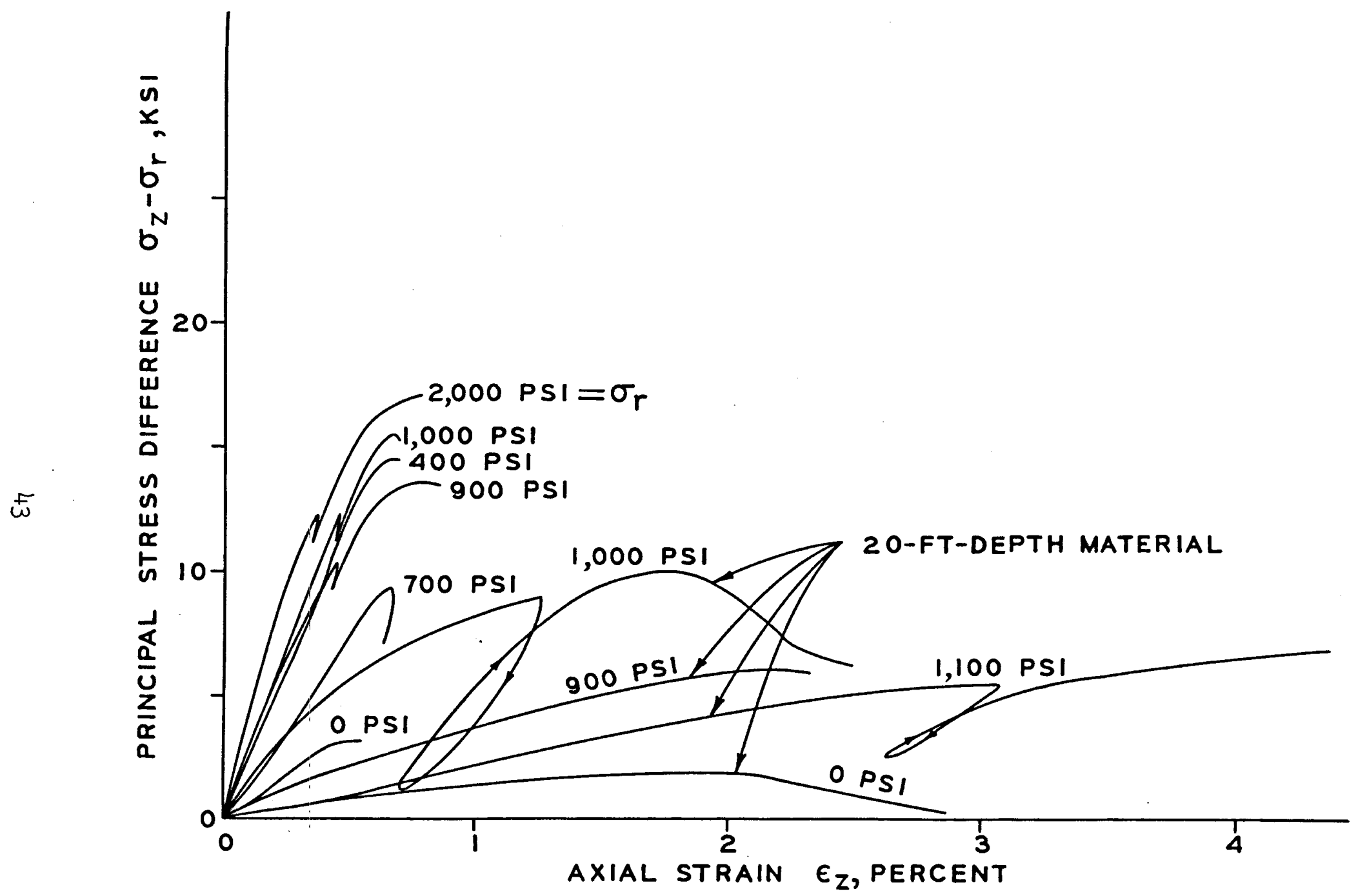

Figure 3.8 Typical dynamic TX shear test results at various confining pressures showing the response of the clayey conglomerate material (from 20-foot depth) and the general response of other Kayenta materials. 


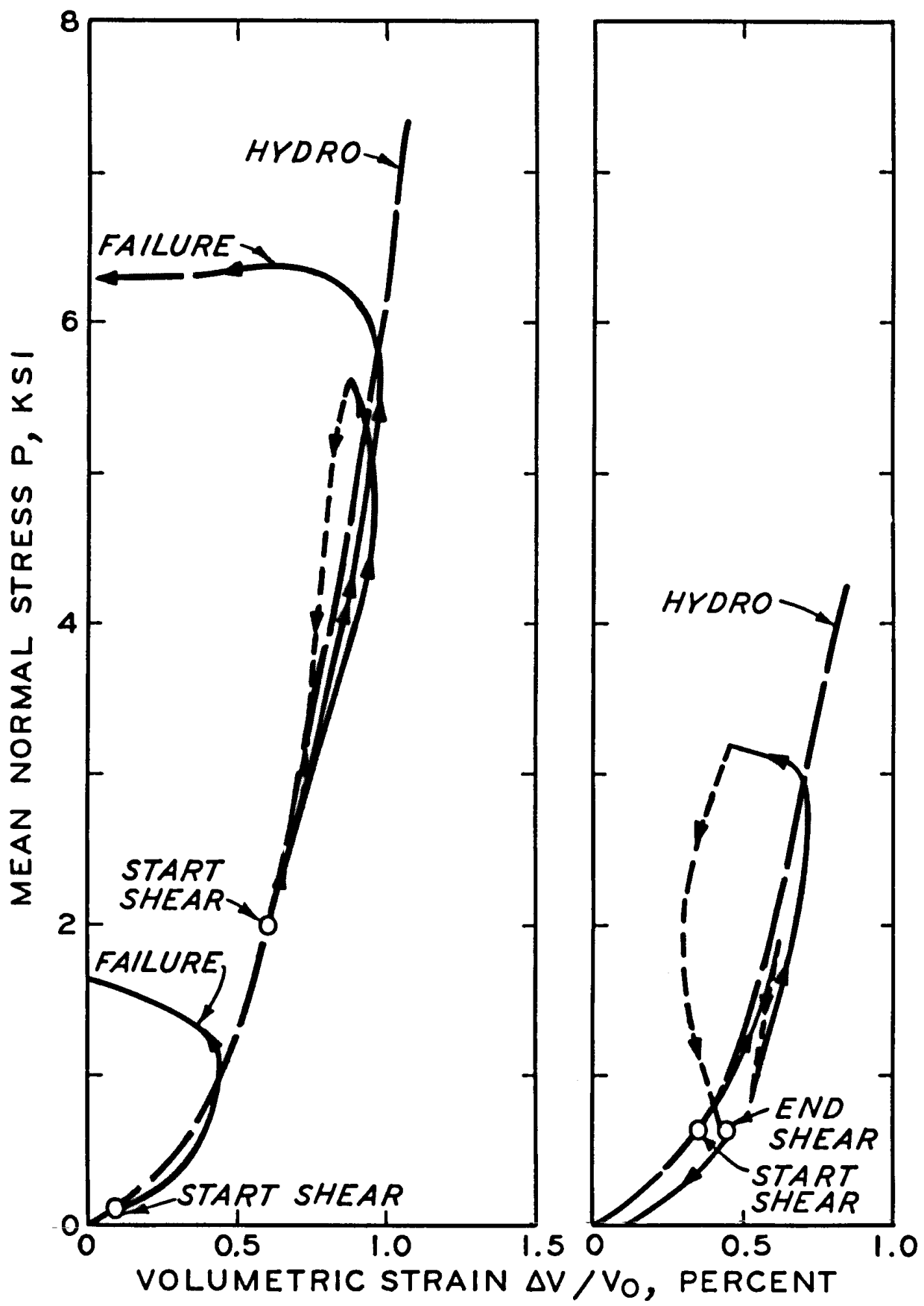

Figure 3.9 Mean normal stress versus volumetric strain showing the typical response of sandstones during TX shear. 


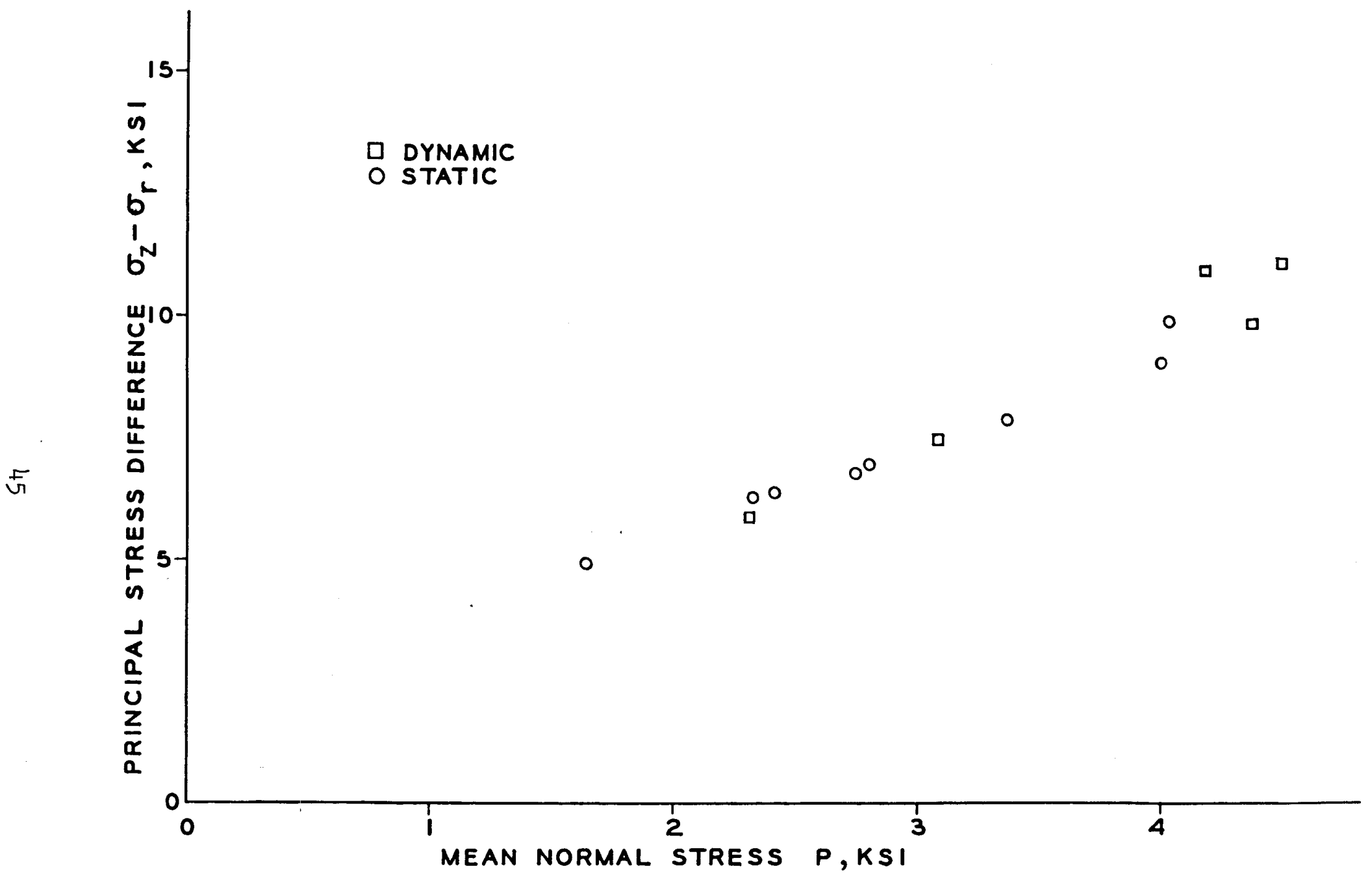

Figure 3.10 Typical static and dynamic TX failure data for sandstones from shallow (<25 feet) depths. 
CHAPTER 4

ANALYSIS

The final task of Project IN 310 was the analysis of the data to develop the computational site profile and corresponding constitutive properties. The analysis involved synthesizing all the available information obtained from the literature, the field investigation, and the laboratory tests into an idealized layered profile and matching set of constitutive properties which hopefully would describe the response of the in situ materials to an imposed dynamic loading. Obviously, in many cases the laboratory data are insufficient and/or not representative of field conditions and assumptions must be made. Judgments must be imposed on data scatter and data trends since numerical averaging does not account for the relative quality of the various items of data. A summary of the procedures or approach used in the analysis is presented in this chapter. The general conclusions that were reached in the assumptions required to fill in the gaps in these findings are also listed herein. The idealized geologic profile and typical examples of the representative properties which were recommended for preshot prediction calculations are shown.

\subsection{APPROACH}

The computational site profile with associated constitutive properties of the Mixed Company Event III site was developed after analyses of all the available information, including the site geology, seismic survey results, boring logs, and composition property data summarized in Chapter 2 and the laboratory stress-strain and strength data discussed in Chapter 3. Where no data existed, such as for the deeper sandstone formations, use was made of literature and unpublished data for similar materials. The information for the various materials encountered was grouped as to material type and/or physical composition properties. The data for each grouping were examined and supplemented where necessary by judgment and/or data from the literature. General conclusions were then reached as to basic data trends and necessary 
assumptions made to relate these trends to qualitative behavior patterns for the recommended in situ constitutive properties. A horizontally layered idealized profile was established and specific values selected for key composition properties, such as density, saturation, and air void content. Finally, a set of constitutive properties consisting of a UX stress-strain relation, a stress path for the UX condition, and a TX failure envelope was quantitatively defined for each layer of the recommended calculational profile.

\subsection{GENERAL CONCLUSIONS AND ASSUMPTIONS}

Two tables are presented which briefly summarize general conclusions and assumptions; Table 4.1 pertains to development of the profile and Table 4.2 to the associated constitutive properties. The statements listed in the two tables are presented solely to indicate some of the gyrations required in order to transform the results of the Mixed Company field and laboratory investigations into a useable format for developing the mathematical constitutive model inputs to ground shock calcuations. Generalization and oversimplification in the statement of many conclusions and assumptions were dictated by the requirement of brevity. The reader is cautioned that these conclusions and assumptions do not apply to any other site; in fact, after analysis of data generated subsequent to June 1972, they may have to be revised substantially even for the Mixed Company III site.

\subsection{SPECIFIC RECOMMENDATIONS}

The site profile and corresponding compositional properties recommended for use in preshot ground shock predictions of Mixed Company Event III are presented in Table 4.3. Properties for the first layer, i.e., the soil overburden, were initially developed based on an assumed 117-pcf wet density for the fill to be constructed along the main gage line. Those properties were amended upon receipt of early construction data which indicated a substantially lower wet density (lll pcf) for this material.

The UX relations for the layers representing the Kayenta materials 
(i.e., Layers II through V) were defined to a stress level of $30 \mathrm{kbar}$; the TX failure envelopes were given to $20 \mathrm{kbar}$. Portions of the UX stress-strain loading-unloading relations recommended for Layers I through $\mathrm{V}$ are shown in Figure 4.1. Figure 4.2 shows representative stress paths for the state of uniaxial strain along with TX failure envelopes for these same five layers. The complete set of properties was furnished to $\mathrm{DNA}^{\mathrm{I}}$ for use in developing model fits by Weidlinger Associates under Project LN 312 and other interested calculators.

1 J. G. Jackson, Jr., letters transmitting Mixed Company site profiles and material property recommendations, to $\mathrm{Mr}$. C. B. McFarland, Defense Nuclear Agency, dated 30 May, 23 June, 29 June, and 10 August 1972, U. S. Army Engineer Waterways Experiment Station, Vicksburg, Miss. 
General Conclusions

1. A berm was placed over the soil at a density approximately equal to the in situ density of the soil at a depth of 2 feet.

2. The natural soil overburden increased in density (95 to $120 \mathrm{pcf}$ ) and degree of cementation down to an indistinct interface with the underlying weathered siltstone of the Kayenta Formation at a depth of 1 to 8 feet.

3. The weathered siltstone encompassed an approximately 4-foot-thick zone; it increased in density with depth from 130 to $140 \mathrm{pcf}$.

4. The remaining portion of the Kayenta Formation could be described as a combination of sandstones, siltstones, mudstones, and conglomerates; no obvious layering pattern, either horizontally or vertically, was discernible. This material had a wide density range $(145 \pm 10 \mathrm{pcf})$.

5. The uniform crossbedded Wingate sandstone occurs at a depth of about 70 feet. The dry density of this material is approximately 120 pcf and is uniform to a depth of at least $150 \mathrm{ft}$ (i.e., the depth of the deepest boring at the site).

6. The geologic investigation indicated that the Wingate Formation extends from a depth of $70 \pm 20$ to $400 \pm 25$ feet.

7. Below the wingate Formation is the Chinle Formation, which extends from a depth of $400+25$ to $500+50$ feet. Precambrian basement rocks underlie the Chinle Formation.

8. The field refraction seismic survey indicated a two-layer profile: 2,000- to 3,000-fps velocities to a depth of about 9 feet and 6,000 - to 8,800 -fps velocities below 9 feet.

9. The weathered siltstone had a rock quality index (RQD) of 0 percent. Unweathered Kayenta materials had RQD's from 90 to 100 percent.
Assumptions

1. The site was idealized as a horizontally layered profile, uniform in all directions.

2. The material comprising each layer was homogeneous and isotropic in all physical properties.

3. The fill over the natural soll resulted in a uniform 5-foot thickness of overburden.

4. The Kayenta Formation could be subdivided into four layers. The uppermost of these was the weathered siltstone. The low-strength and low-moduli clayey conglomerate, which occurred randomly throughout the formation, was assumed to be lumped into a single stratum which formed the third idealized Kayenta layer. The second and fourth layers were based on the properties of more competent specimens from the upper one-third and the lower two-thirds of the formation, respectively.

5. The Wingate and Chinle Formations and Precambrian basement rock each comprised a layer.

6. The seismic velocity of the weathered siltstone portion of the Kayenta was 2,500 fps. The seismic velocity of the three underlying layers in this formation was assumed to be approximately 7,500 fps.

7. The seismic velocity of the Wingate Formation was assumed to be no greater than that of the deeper part of the $\mathrm{Ka}-$ yenta (i.e., 7,500 fps). The velocity of the Chinle Formation was assumed to be 9,000 fps, i.e., somewhat higher than those of the Kayenta and Wingate Formations.

8. A $15,000-f p s$ seismic velocity was assumed for the Precambrian rocks.

9. None of the formations in the profile were assumed to be saturated. 
1. Only the data available by June 1972 would be used to develop representative properties for the preshot calculations.

2. A.ll tests were performed on vertically oriented specimens. Most tests were conducted on specimens that were large enough to include some nonuniformities such as clay seams and/or natural fractures.

3. The laboratory tests were conducted with times to peak stress ranging from several microseconds to several seconds.

4. Most specimens that were tested at peak stress levels less than $1 \mathrm{kbar}$ had their in situ water contents preserved. Most specimens tested at higher pressures were tested in an air-dried condition.

5. The soil UX and $T X$ response was dominated by the influence of density and water content variations. Some effects due to loading rate were also observed. 6. The weathered siltstones and unweathered clayey conglomerates of the Kayenta Formation were considerably more compressible and somewhat weaker than the unweathered Kayenta sandstones, siltstones, and madstones.

7. For specimens tested with loading times ranging from seconds to milliseconds, the UX curves were initially soft but stiffened gradually under stresses up to 1,000 psi; thereafter, a marked stiffening was noted. Rate effects were indistinguishable due to the dominance of other variables. UX gun test data with microsecond loading rates indicated much stiffer initial loading moduli, 1.e., values comparable to those observed at the highest stress levels in the slower tests.

8. For TX specimens tested with loading times ranging from seconds to milliseconds, the influences due to rate of loading were also indistinguishable due to scatter resulting from other more dominant variables.

9. Horizontal tensile strengths, as indicated by Brazil test results, were up to five times the vertical tensile strengths indicated by results of direct-pull tests. Although the quantitative validity of the Brazil test results is questionable, they definitely indicate that horizontal tensile strengths equal or exceed vertical strengths.
Assumptions

1. The times to peak stress anywhere within the site due to the expected detonation would be on the order of several milliseconds.

2. All materials were assumed to be isotropic, in spite of conflicting tensile test evidence. All reconmended properties, including those for tension, were based on vertically orlented test specimens.

3. The density and water content of the constructed fill or berm should be used as the basis for selecting representative properties for Layer $I$.

4. At low stress levels ( $\ll 10 \mathrm{ps} 1$ ), the initial UX moduli would be equal to moduli calculated from field seismic velocities. At pressures above the level of structural collapse, the UX stress paths of the Kayenta materials would be similar to those observed for sand.

5. Many of the open fractures found in samples from the weathered Kayenta siltstone (Layer II) were due to sampling disturbances; therefore, initial strains in excess of 2 percent resulting under UX tests loadings less than 10 psi were lgnored.

6. A major proportion of the in situ mass of weathered Kayenta siltstones (Layer II) contained numerous healed cracks, laminations, and fibrous root systems; therefore, recomnended compression properties were weighed in favor of UX test results from specimens containing such features.

7. Since insufficient TX data were available for the weathered siltstones (Layer II) to define shear behavior, strength data for unweathered materials could be reduced arbitrarily to define weathered strengths.

8. For the unweathered materials, since rock quality index values were always greater than 90 percent, responses observed for laboratory tests on specimen cores adequately depicted in situ mass behavior.

9. Laboratory test results for sandstone, siltstone, and mudstone specimens obtained from the upper onethird of the unweathered Kayenta Formation adequately depicted the in situ mass behavior of Layer III.

10. Laboratory test results for clayey conglomerate specimens obtained from throughout the unweathered Kayenta Formation adequately depicted the in situ mass behavior of the extremely 1dealized Layer IV.

11. Laboratory test results for sandstone, siltstone, and mudstone specimens obtained from the lower two-thirds of the unweathered Kayenta Formation adequately depicted the in situ mass behavior of Layer $\mathrm{V}$.

12. Layer VI represented the Wingate Formation and was slightly softer in compression and slightly weaker in shear than Layer $V$ because of its higher porosity and markedly lower density.

13. Layers VII and VIII represented the Chinle Formation and Precambrian basement rock, respectively, and behaved as linearly elastic materials; properties were based on data found in the literature for other rocks of the same type and age. 
TABLE 4.3 REPRESENTATIVE PROFILE AND COMPOSITIONAL PROPERTIES

\begin{tabular}{|c|c|c|c|c|c|c|c|}
\hline Depth & Layer & $\begin{array}{l}\text { Wet } \\
\text { Density }\end{array}$ & $\begin{array}{l}\text { Dry } \\
\text { Density }\end{array}$ & Saturation & $\begin{array}{l}\text { Volume } \\
\text { of Air }\end{array}$ & $\begin{array}{l}\text { Seismic } \\
\text { Compression } \\
\text { Velocity }\end{array}$ & Material Type \\
\hline
\end{tabular}

\begin{tabular}{|c|c|c|c|c|c|c|c|}
\hline feet & & pef & $p c f$ & percent & percent & fps. & \\
\hline 0 to 5 & I & 111.3 & 104.0 & 31.0 & 25.9 & 1,800 & Soil overburden \\
\hline$>5$ to 9 & If & 137.0 & 132.4 & 36.7 & 12.8 & 2,500 & Weathered Kayenta siltstone \\
\hline$>9$ to 18 & III & 147.0 & 140.7 & 66.5 & 5.1 & 7,100 & Upper Kayenta materials \\
\hline$>18$ to 22 & IV & 154.0 & 148.1 & 80.6 & 2.3 & 7,500 & Soft Kayenta material \\
\hline$>22$ to 70 & $\mathrm{v}$ & 147.0 & 140.7 & 66.5 & 5.1 & 7,500 & Lower Kayenta material \\
\hline$>70$ to 400 & $\mathrm{VF}$ & 128.4 & 120.0 & 49.1 & 14.0 & 7,400 & Wingate Formation \\
\hline$>400$ to 500 & VII & 158.0 & -- & -- & -- & 9,000 & Chinle Formation \\
\hline$>500$ & VIII & 162.0 & -- & -- & -- & 15,000 & Precambrian basement rock \\
\hline
\end{tabular}




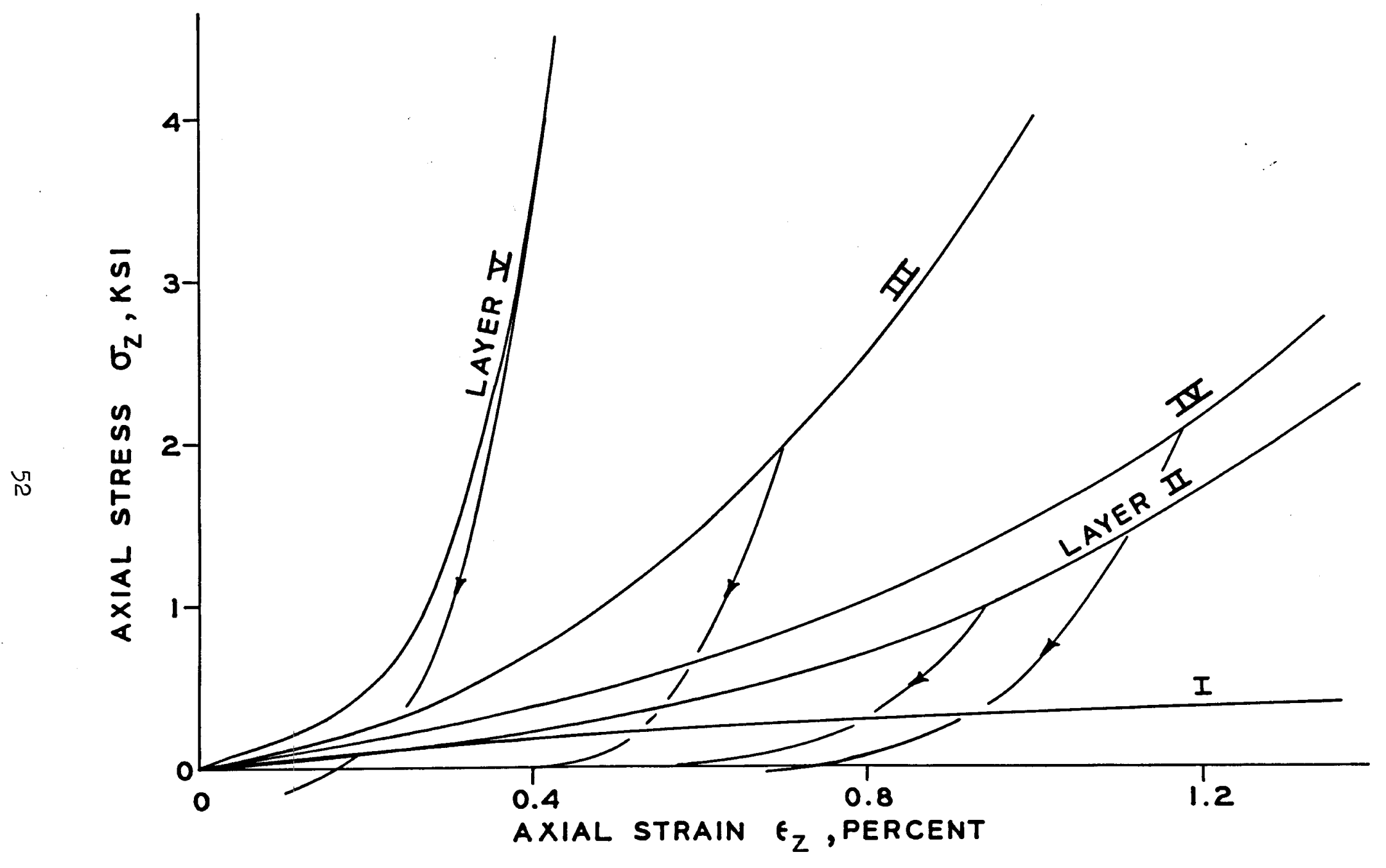

Figure 4.1 Representative UX stress-strain loading and unloading relations for Layers I through $\mathrm{V}$. 

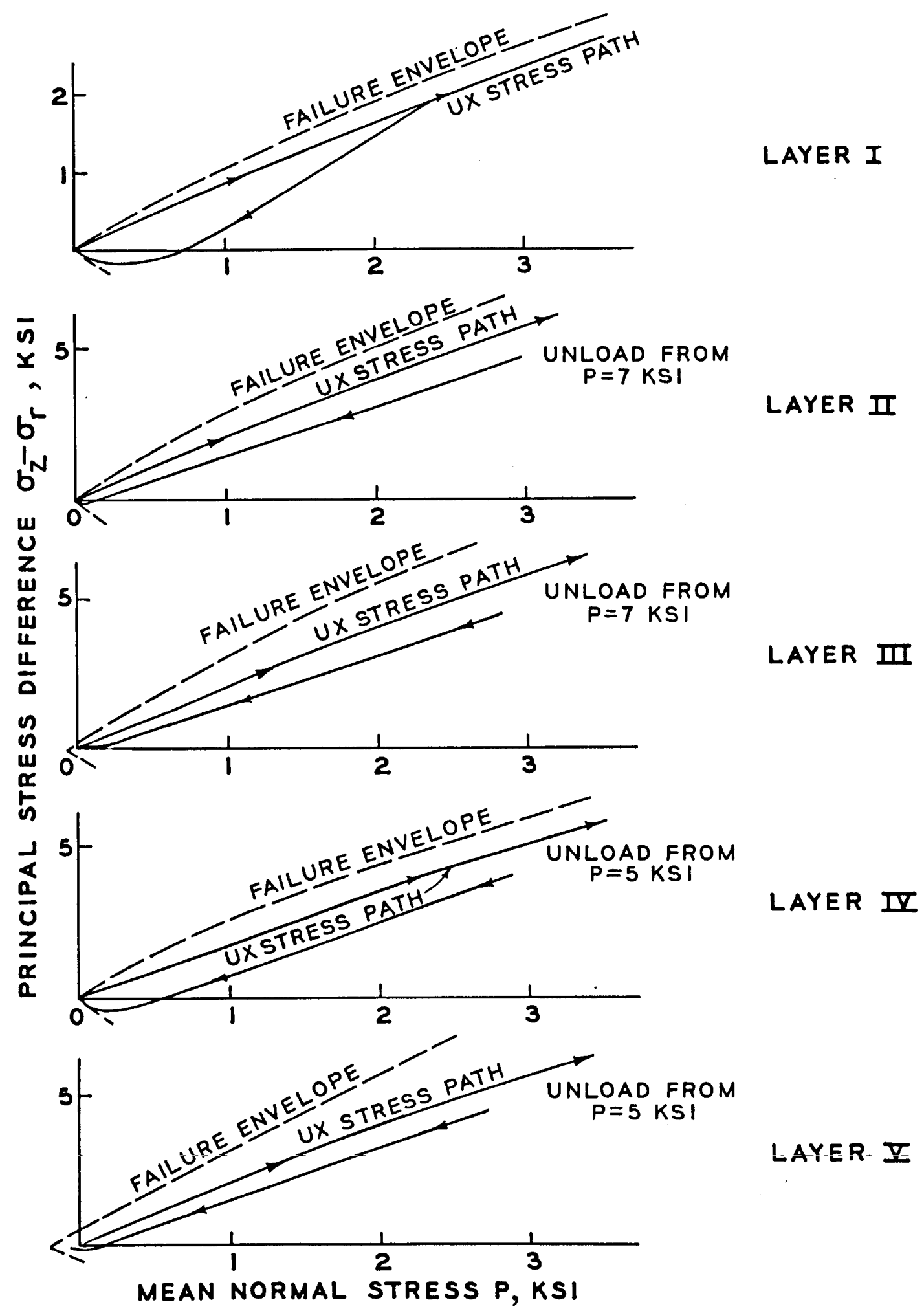

Figure 4.2 Representative UX stress paths and TX failure envelopes for Layers I through V. 
The purpose of this report was to summarize the preshot field and laboratory work performed under Project IN 310, "Soil Sampling and Laboratory Testing for Constitutive Relations." The site geology as well as the field and laboratory test programs carried out have been described. Typical test results and the representative constitutive properties furmished for use in preshot calculations have been presented. While it was necessary, for the purposes of calculations, to idealize the near-surface sedimentary rocks of the Kayenta Formation into a few homogeneous layers, the data indicate considerable variation in lithology and constitutive properties within this formation. Thus, while the siting objective of obtaining a shallow soil layer was achieved, the data indicate that in a strict sense the objective of obtaining a nearly uniform underlying sandstone stratum was not achieved. 


\section{Department of Defense}

Assistant to the Secretary of Defense (Atomic Energy)

ATTN: Document Control

Washington, D. C. 20301

Director of Defense Research \& Engineering

ATTN: Dep Dir (Info \& Space Systems)

Dep Dir (Strategic Systems)

1

Washington, D. C. 20301

Director

Defense Nuclear Agency

ATTN: SPSS

APTL

1

APSI

Washington, D. C. 20305

Director

Advanced Research Projects Agency

ATTN: NMRO

1400 Wils on Boulevard

Arlington, Va. 22209

Director

Defense Civil Preparedness Agency

ATTN: RE-SR, Mr. George Sisson

Washington, D. C. 20301

Defense Documentation Center

ATTN: Mr. Myer Kahn

Cameron Station

Alexandria, Va. 22314

Commander, Field Command

Defense Nuclear Agency

ATTN: FCTD, Director

FCTD-3, Document Control

FCTD-T, Dr. Benjamin Grote

Kirtland Air Force Base, N. Mex. 87115

Commander, Field Command

Defense Nuclear Agency

ATTN: FCTD-N, Mr. J. W. LaComb

P. O. Box 208

Mercury, Nev. 89023 


\section{Department of Defense (Cont'd)}

Commandant

Industrial College of the Armed Forces

ATIN : Document Control

Fort Lesley J. McNair

Washington, D. C. 20315

Director

Joint Strategic Target Planning Staff

ATTN : JLTW

Offutt Air Force Base

Omaha, Nebr. 68113

Commander, Field Command

Defense Nuclear Agency

ATTN: Livermore Division Document Control

Lawrence Livermore Laboratory

P. 0. Box 808

Livermore Calif. 94550

Commandant

National War College

ATTN : Document Control

Fort Lesley J. McNair

Washington, D. C. 20315

Department of the Army

Chief of Research and Development

Department of the Army

ATTN: Director of Army Technical Information

Washington, D. C. 20310

Commander

Harry Diamond Laboratories

ATTN: AMXDO-NP, Mr. Louis Belliveau/Mr. J. H. Gwaltney

Connecticut Avenue at Van Ness, N. W.

Washington, D. C. 20438

Office, Chief of Engineers, Department of the Army

ATTN: DAEN-ASI-L

DAEN-MER-D/Mr. P. F. Carlton

DAEN-MCE-D/Mr. M. L. Martin

DAEN-MCZ-S/COI J. S. C. Smith

Washington, D. C. 20314 
Department of the Army (Con't)

Division Engineer, U. S. Army Engineer Division

ATTN: HNDED-R (Mr. M. M. Dembo)

P. 0. Box 1600 , West Station

Huntsville, Ala. 35807

SAFEGUARD System Manager

U. S. Army SAFEGUARD System Office

ATTN: Dr. John Shea

1320 Wilson Boulevard

Arlington, Va. 22209

Commanding General

U. S. Army SAFEGUARD System Command

ATTN: SSC-DH

$$
\text { SSC-HS (Mr. H. M. Porter) }
$$

SSC-HM (MAJ R. A. Larochelle)

P. 0. Box 1600 , West Station

Huntsville, Ala. 35807

Commandant

U. S. Army Engineer School

ATTN: Library

Fort Belvoir, Va. 22060

Director

U. S. Army Ballistic Research Laboratories

ATTN: Technical Library

Aberdeen Proving Ground, Md. 21005

Director

U. S. Army Engineer Construction Engineering Research Laboratory

ATTN: Library Mr. J. Healy

P. O. Box 4005

Champaign, Ill. 61820

Director

Explosive Excavation Research Laboratory

U. S. Army Engineer Waterways Experiment Station

P. O. Box 808

Livermore, Calif. 94550 


\section{Department of the Army (Con't)}

Commander and Director

U. S. Army Cold Regions Research and Engineering Laboratory

ATTN: Library

$$
\text { Dr. D: R. Freitag }
$$

P. O. Box 282

Hanover, N. H. 03755

U. S. Army Strategic Communications Command

SAFEGUARD Communications Agency

ATTN: Mr. Klaus Donat

Fort Huachuca, Ariz. 85613

Director

Advanced Ballistic Missile Defense Agency

ATTN: MAJ E. V. De Bosier

Commonwealth Building

1320 Wilson Boulevard

Arlington, Va. 22209

Commander

U. S. Army Combat Development Command

Institute of Nuclear Studies

ATTN: Document Control

Fort Bliss, Tex. 79916

Commander

U. S. Army Materials and Mechanics Research Center

ATTN: Library

Watertown, Mass. 02172

Department of the Navy

Commander

Naval Facilities Engineering Command

Command Headquarters

ATTN: Library

Washington, D. C. 20390

Commanding Officer

U. S. Naval Civil Engineering Laboratory

ATTN: Library

Dr. Warren A. Shaw

$\mathrm{Mr}$. J. R. Allgood

1

1

1

Port Hueneme, Calif. 93041 
Department of the Navy (Cont'd)

Commander

Naval Electronics Systems Command

Special Communications Project Office (PME 117-21)

ATTN: ICDR E. Frevert

Mr. J. D. Day

Washington, D. C. 20360

Chief of Naval Operations

Department of the Navy

ATTN: OP-985

Washington, D. C. 20350

Chief or Naval Research

Department of the Navy

ATTN: Document Control

Arlington, Va. 22217

Department of the Air Force

Commander

Air Force Weapons Laboratory. (AFSC)

ATTN: DOGL, Technical Library

DEV, LTC R. M. Goodwin

DEV, MAJ G. V. Bulin, Jr.

DEV, Mr. G. L. Bratton

DEV, Mr. R. J. Port

Kirtland Air Force Base, N. Mex . 87117

Director of Civil Engineering

Headquarters, U. S. Air Force

ATTN: AFOCE, Technical Library

Washington, D. C. 20333

Deputy Chief of Staff for Research and Development

Headquarters, U. S. Air Force

ATTN: AFRD, Technical Library

Washington, D. C. 20330

Commander

Air Force Systems Command

ATTN: DEE

Andrews Air Force Base

Washington, D. C. 20331 
Department of the Air Force (Cont'd)

Commander, Air Force Cambridge Research Laboratories (AFSC)

ATTN : Research Library

Dr. Ker Thompson

L. G. Hanscom Field

Bedford, Mass. 01730

Commander, Space and Missile Systems Organization (AFSC)

ATTN: MNNH, MAJ Mel Castillo

$\mathrm{DEB}$, CAPT R. A. Guarino

Norton Air Force Base, Calif. 92409

Air Force Institute of Technology

ATTN : AFIT-L

Building 640

Wright-Patterson Air Force Base, Ohio 45433

Commander, Space and Missile Systems Organization (AFSC)

ATTN : Technical Library

P. 0. Box 92960

Worldway Postal Center

Los Angeles, Calif. 90009

Other Government Agencies and Contractors

U. S. Atomic Energy Commission

Nevada Operations Office

ATTN: Technical Library

P. 0. Box 14100

Las Vegas, Nev. 89114

Sandia Laboratories

ATTN: Technical Library

1 Mr. C. W. Gulick, Jx.

P. O. Box 5800

Kirtland Air Force Base East, N. Mex. 87115

University of California

Lawrence Iivermore Laboratory

Technical Information Division

ATTN: Technical Library

1

Dr. Douglas Stephens

1

Dr. Robert Schock

Dr. Hugh Heard

P. O. Box 808

Livermore, Calif. 94550 
Other Government Agencies and Contractors (Cont'd)

U. S. Bureau of Mines

ATTN: Technical Library

Building 20, Denver Federal Center

Denver, Colo. 80225

Agbabian Associates

ATTN: Document Control

Dr. M. S. Agbabian

1

Dr. J. Isenberg

1

250 North Nash Street

El Segundo, Calif. 90245

Applied Theory, Incorporated

ATTN: Dr. John G. Trulio

Mr. N. K. Perl

1

1010 Westwood Boulevard

Los Angeles, Calif. 90024

General Electric Company, TEMPO

ATTN: Dr. Warren W. Chan (DASIAC)

816 state Street

Santa Barbara, Calif. 93101

Systems, Science and Software

ATTN: Document Control

Dr. D. R. Grine

Dr. T. R. Blake

Dr. R. L. Bjork

Dr. T. J. Cherry

Dr. T. D. Riney

Dr. R. T. Allen

Dr. E. S. Gaffney

P. 0. Box 1620

La Jolla, Calif. 92037

Shock Hydrodynamics, Incorporated

ATTN: Dr. L. Zernow

Dr. G. Ialongo

15010 Ventura Boulevard

Sherman Oaks, Calif. 91403

Physics International Company

ATTN: Mr. Fred M. Sauer

Dr. Robert Swift

2700 Merced street

San Leandro, Calif. 94577 
Other Government Agencies and Contractors (Cont'd)

TRW Systems Group

ATTN: Dr. Peter Dai (Mail Station No. Rl/2178)

$\mathrm{Mr}$. Norman Lipner (Mail Station No. Rl/2178)

One Space Park

Redondo Beach, Calif. 90278

Consulting and Special Engineering Services, Inc.

ATTN: Dr. J. L. Merritt

P. 0. Box 1206

Redlands, Calif. 92373

McDonnell-Douglas Astronautics Company

MS-9, Building 11-12

ATTN: Dr. J. G. Logan

$\mathrm{Mr}$. Ken McClymonds

5301 Bolsa Avenue

1

Huntington Beach, Calif. 92647

Teledyne Brown Engineering, MS-44

ATTN: Mr. Jack Cahoon, Jr.

1

Dr. M. C. Patel

300 Sparkman Drive

Huntsville, Ala. 35807

TRW Systems Group

ATTN: Mr. Fred A. Pieper $/$ Rm. 720

Building 527, Norton AFB

San Bernardino, Calif. 92402

Weidlinger Associates

ATTN: Dr. M. L. Baron

1

Dr. Ivan Nelson

1

Dr. Ivan Sandler

$\mathrm{Mr}$. Joseph P. Wright

1

110 East 59th Street

1

New York, N. Y. 10022

Shannon and Wilson, Incorporated

ATTN: Mr. Earl A. Sibley

$\mathrm{Mr}$. T. C. Kinney

1105 North 38th Street

Seattle, Wash. 98103 
R\&D Associates

ATTN : Dr. Harold L. Brode

Dr. H. F. Cooper, Jr.

P. 0. Box 3580

Santa Monica, Calif. 90403

Stanford Research Institute

ATTN: Dr. Carl Peterson

333 Ravenswood Avenue

Menlo Park, Calif. 94025

The Boeing Company, Aerospace Group

Missile \& Information Systems Division

ATTN: Mr. Robert Hager

P. 0. Box 3707

Seattle, Wash. 98124

California Research and Technology, Inc.

ATTN: Dr. K. N. Kreyenhagen

6269 Variel Avenue, Suite 200

Woodland Hills, Calif. 91364

Martin Marietta Corporation, Orlando Division

ATTN: Mr. Jim Wagner, MP 377

P. O. Box 5837

Orlando, Fla. 32805

Terra Tek, Inc.

ATTN: Mr. S. J. Green

Dr. A. H. Jones

University Research Park

420 Wakara Way

Salt Lake City, Utah 84108

\section{Colleges and Universities}

George Washington University

Department of Engineering Mechanics

ATTN: Dr. A. Freudenthal

Washington, D. C. 20006

University of Illinois

Department of Civil Engineering

ATTN: Professor N. M. Newmark

Professor A. J. Hendron, Jr.

Urbana Campus

Urbana, Ill. 61801 
Colleges and Universities (Cont'd)

University of Michigan

Department of Civil Engineering

ATTN: Professor F. E. Richart, Jr.

304 West Engineering

Ann Arbor, Mich. 48104

University of Utah, College of Engineering

Department of Mechanical Engineering

ATTN: Dr. Wayne Brown

Salt Lake City, Utah 84112

University of New Mexico

Civil Engineering Research Facility

ATTN: Mr. Delmar E. Calhoun

P. 0. Box 188, University Station

Albuquerque, N. Mex. 87106

Massachusetts Institute of Technology

Division of Sponsored Research

ATTN: Professor Robert V. Whitman

1

Professor William F. Brace

1

77 Massachusetts Avenue

Cambridge, Mass. 02139

University of Oklahoma

Department of Information and Computing Science

ATTIN: Dr. J. C. Thompson

905 Asp

Norman, Okla. 73069

California Institute of Technology

ATTN: Dr. Thomas J. Ahrens

1201 East California Boulevard

Pasadena, Calif. 91109

Texas A\&M University

College of Geosciences

Center for Tectonophysics

ATTN: Dr. John Handin, Director

College Station, Tex. 77843

Georgia Institute of Technology

School of Civil Engineering

ATTN: Dr. B. B. Mazanti

Atlanta, Ga. 30332 


\section{Colleges and Universities (Con't)}

Washington State University

Dept of Physics

ATTN: Dr. George Duvall

Pullman, Wash. 99163 
Unclassified

Security Clas sification

\section{DOCUMENT CONTROL DATA - R \& D .}

(Socurity clessification of tille, body of ebstract and indexting ennotetion muat be entered when the overall roport le cleseltled,

U. S. Army Engineer Waterways Experiment Station

Vicksburg, Miss.

20. REPORT SECURITY CLABSIFICATION Unclassified

2b. GROUP

\section{REPORT TITLE}

PRESHOT MATERIAI PROPERTY INVESTIGATION FOR THE MIXED COMPANY SITE: SUMMARY OF SUBSURFACE EXPLORATION AND IABORATORY TEST RESULTS

\section{OESCRIPTIVE NOTES (TYPO Ol roport and Incluoive datee)}

Final report

8. AUTHOR(S) (FIrot namo, middio Initial, last namo)

John Q. Ehrgott

\begin{tabular}{|c|c|}
\hline $\begin{array}{l}\text { - REPORT DATE } \\
\text { October } 1973\end{array}$ & $\begin{array}{l}\text { 70. TOTAL NO. OF PAGES } \\
67\end{array}$ \\
\hline $\begin{array}{l}\text { D. CONTRACT OR GRANTNO. } \\
\text { B. PROJECT NO. } \\
\text { Subtask SB209, Work Unit } 11\end{array}$ & $\begin{array}{l}\text { 90. ORIGINATOR'S REPORT NUMBER(3) } \\
\text { Miscellaneous Paper S-73-62 }\end{array}$ \\
\hline c. & $\begin{array}{l}\text { Db. OTHER REPORT NO(S) (Any other numbere that may be eloelened } \\
\text { this mepOrt) }\end{array}$ \\
\hline
\end{tabular}

Approved for public release; distribution unlimited.

\begin{tabular}{|c|c|}
\hline 11. SUPPLEMENTARY NOTES & $\begin{array}{l}\text { 12. SPONSORING MILITARY ACTIVITY } \\
\text { Defense Nuclear Agency, } \\
\text { Washington, D. C. }\end{array}$ \\
\hline
\end{tabular}

This report summarizes the investigations conducted under Project LN 310, "Soil Sampling and Laboratory Testing for Constitutive Relations," in support of Mixed Company Event III, a 500-ton, high-explosive experiment conducted near Grand Junction, Colorado. The primary purpose of Project LN 310 was to provide a representative geologic profile of the Mixed Company site along with associated constitutive properties for use in the preshot two-dimensional ground shock calculations planned under Project IN 312. This report describes results from (1) a field investigation program consisting of a geologic survey, a refraction seismic survey, and an exploration boring and sampling program; (2) a laboratory test program consisting of static and dynamic uniaxial strain tests, isotropic compression tests, triaxial shear tests, and static tension tests; and (3) the analyses applied to the data obtained from both of these programs in order to develop a recommended site profile and matching set of constitutive properties in time to support preshot calculations. Typical test data are presented to illustrate general trends and/or response characteristics. 
Unclassified

Security Classification

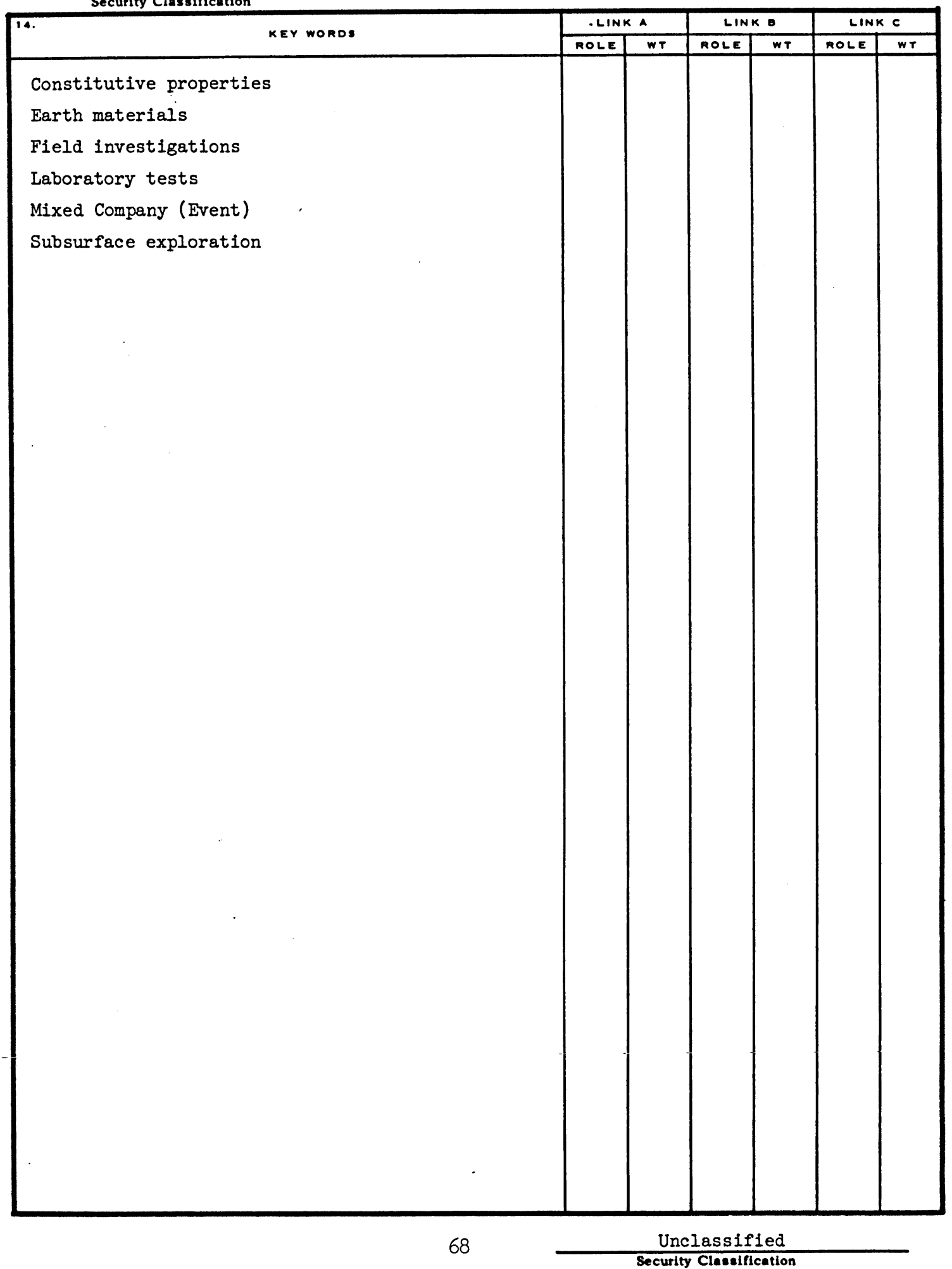

